УДК 551.31:551.736.1(470.53)

\title{
ЛИТОЛОГО-ФАЦИАЛЬНОЕ СТРОЕНИЕ УФИМСКИХ ОТЛОЖЕНИЙ ЦЕНТРАЛЬНОЙ ЧАСТИ ПЕРМСКОГО КРАЯ
}

\author{
Плюснин Алексей Владимирович1, \\ A.V.Plyusnin@mail.ru
}

\section{Сулима Александр Иванович 1 ,} super.sulima2013@yandex.ru

\author{
Тимофеев Владислав Дмитревич1, \\ immrill@yandex.ru
}

\author{
Коваль Дмитрий Валерьевич1, \\ koval0806@yandex.ru
}

\author{
Дементьева Ксения Владимировна 1 , \\ demksevla@yandex.ru \\ 1 Пермский государственный национальный исследовательский университет, \\ Россия, 614068, Пермь, ул. Букирева, 15.
}

\begin{abstract}
Актуальность исследования обусловлена необходимостью уточнения литолого-фациального и секвенсстратиграфического строения отложений пермской системы. На сегодняшний день существует проблема стратиграфического положения и самостоятельности уфимского яруса. За последние три десятилетия исследователи высказывали разные предположения об изменении объемов яруса. Из-за особенностей осадконакопления основными биостратиграфическими группами для Волго-Камского региона являются: остракоды, пелециподы, споры и пыльца, растительные остатки, фрагменты рыб и позвоночных, интервалы распространения которых ограничены границами фрациальных зон. Отсюда и возникают сложности в определлении грании и объёма яруса биостратиграфическими методами.

Цель: разделение отложений на секвенсы четвертого порядка и уточнения литолого-фациального строения.

Объекты: геологические разрезы и глубокие скважины центральной части Пермского края.

Методы: геокартирование геологических разрезов; скважинная корреляция; литолого-фрациальное описание; палеогеографические реконструкции.

Результаты. Проведение корреляции наиболее типичных разрезов помогло авторам описать строение, вещественньй состав и построить сводный разрез уфимского яруса. Субмеридиональный профиль по изученным скважинам позволил показать смену типов разреза по площади от максимальных толщин в районе Соликамской и Висимской впадины, до нормальных в платформенной части Пермского края. В разрезе усимского яруса выделено два секвенса четвертого порядка. Первый секвенс по объёму соответствует нижнесоликамской подсвите. Второй секвенс выделен в объёме верхнесоликамской подсвиты и шешминской свиты. Зафиксировано стратиграфическое несогласие с признаками субаэральной экспозиции на границе кунгурского и уфимского яруса и нижне- и верхнесоликамской подсвиты.
\end{abstract}

\section{Ключевые слова:}

Стратиграфия, пермская система, уфимский ярус, секвенс-стратиграфия, литофрациальная изменчивость.

\section{Введение}

На сегодняшний день существует проблема стратиграфического положения и самостоятельности уфимского яруса. Хронология представлений о его месте в стратиграфической шкале приводится в работе С.В. Наугольных: звучали предложения изменить объем этого яруса, оставив в нем только шешминский горизонт, а соликамский горизонт отнести к кунгурскому ярусу [1]. Предлагалось рассматривать соликамский горизонт в качестве самостоятельного яруса верхнего отдела перми [2]. Также предлагалось сохранить уфимский ярус в прежнем объеме, но отнести его к нижнему отделу пермской системы [3] или к ее среднему отделу (как вариант, к нижнему подотделу верхнего отдела пермской системы) [4] или даже полностью упразднить уфимский ярус, отнеся соликамский горизонт к кунгурскому ярусу, а шешминский горизонт - к казанскому ярусу [5].
Из-за особенностей осадконакопления основными биостратиграфическими группами для уфимского яруса Волго-Камского региона являются: остракоды, пелециподы, споры и пыльца, растительные остатки, фрагменты рыб и позвоночных, интервалы распространения которых связаны с границами фациальных зон. Отсюда и возникает ограниченность биостратиграфических методов, из-за которых исследователям до сегодняшнего дня не удавалось четко определить границы и объём уфимского яруса.

Авторами выполнена стратификация разреза уфимского яруса при помощи не биостратиграфических методов, а методом лито-стратиграфии и секвенсстратиграфии. Для этого проведены литологофациальные, цикло-стратиграфические и палеогеографические исследования на территории стратотипического региона, которые помогли произвести оценку сходства и различия процессов формирования соликамского 
и шешминского горизонтов, восстановить последовательность осадконакопления. Полученные результаты позволят по-новому взглянуть на уфимский ярус и с позиций секвенс-стратиграфии разделить данную толщу, что явилось основной целью данной работы.

\section{История изучения}

Разнообразие вещественного состава пород и их пригодность для народного хозяйства объясняется историей геологического развития, особенностями седиментации и вторичного минералообразования уфимских отложений. На исследуемой территории начиная с 1723 г. работало несколько медеплавильных заводов. Ограниченность запасов отдельных залежей меди вынуждала вести постоянные поиски новых месторождений [9].

Наиболее важный этап в геологических исследованиях в окрестностях Перми начался в 1842 г. с выделением пермской системы шотландским геологом Р.И. Мэрчисоном и его российским коллегой Н.И. Кокшаровым.

В 1860-х гг. создаются геологические карты Урала и Европейской части России (Г.П. Гельмерсен, Э.И. Гофман), а Н.А. Головкинский установил цикличность и условия осадконакопления верхнепермских отложений. В конце XIX в. были проведены детальные съёмки и А.Л. Краснопольским составлена геологическая карта 126 листа (Пермь-Соликамск) [7].

Собственно, уфимский ярус выделен А.Н. Нечаевым в 1915 г., в бассейне нижнего течения р. Белая, как нижний ярус в общей шкале пермской системы и окончательно утвержден Межведомственным стратиграфическим комитетом только в 1960 г. Соликамская свита выделена Г.Н. Фредериксом в 1932 г., шешминская свита выделена коллективом авторов в 1960 г. и пришла на смену уфимской свите. Названы они по городу Соликамску и реке Шешма в Татарстане [8].

В этот период уфимские отложения обозревались в работах Н.Д. Кованько, Е.Н. Ларионова, П.А. Софроницкого, М.Э. Ноинского и др. Финалом этих работ стало издание в 1939 г. геологической карты листа О-40 (А.И. Морозов, И. И. Горский).

На конференции ВНИГРИ в мае 1950 г. выделена уфимская свита, упорядочены границы вышезалегающих белебеевской и казанской свит. Статьи по этой тематике также публиковали Б.И. Грайфер, В.П. Золотова и Н.Н. Форш. В 1959-1965 гг. Ю.А. Нечаевым выполнялись ревизионные работы по оценке пермских медистых песчаников [7,9].

В 1963 г. проводятся работы по унификации стратиграфической схемы Русской платформы и впервые официально выделяется уфимский ярус, который был отнесен к основанию верхнего отдела перми. Для соликамских и шешминских отложений в 1966 г. А.М. Кутергин, Б.П. Белых, М.И. Денисов составили литолого-палеогеографические карты. На следующий год коллектив ученых под руководством В.П. Горского (ВСЕГЕИ) увязали этапы тектонического развития с ярусами пермской системы $[10,11]$.

Летом 1991 г. был проведён международный конгресс «Пермская система земного шара», к которому были обобщены сведения по геологии и изданы путеводители и сборники докладов. Хорошими путеводителями служат пособия по геологической практике для студентов, изданные В.И. Копниным [12] и А.С. Сунцевым [9]. В дальнейшем А.С. Сунцевым было произведено разделение соликамской свиты на пачки [13]. Биостратиграфии соликамских отложений посвящены работы В.В. Силантьева $[14,15]$. Палеоботанические и фитостратиграфические работы по уфимскому ярусу опубликованы С.В. Наугольных [5, 16-18]

8 апреля 2005 г. на расширенном заседании Бюро МСК было принято постановление о модернизации верхнего отдела пермской системы ВосточноЕвропейской стратиграфической шкалы. Уфимский ярус был присоединен к нижнему (приуральскому) отделу пермской системы.

\section{Краткие сведения о геологическом строении}

Исследуемая площадь в административном отношении расположена на территории Пермского, Добрянского, Нытвенского, Краснокамского и Осинского районов, в центральной части Пермского края. Район работ относится к бассейну Камы и её крупных притоков: Чусовой и Сылвы.

Рассматриваемая территория в тектоническом плане расположена на востоке Восточно-Европейской платформы. На дневную поверхность в районе исследования выходят отложения иренского горизонта кунгурского яруса и соликамского, шешминского горизонтов уфимского яруса. Согласно принятой стратиграфической схеме уфимский ярус относится к нижнему приуральскому отделу пермской системы. В публикации [10] авторами приводятся доводы, доказывающие необходимость отнесения уфимского яруса к нижнему подотделу среднего отдела пермской системы. Авторы настоящего исследования поддерживают его и принимают в качестве стратиграфической основы.

Иренский горизонт представлен иренской свитой, на дневную поверхность в изучаемом районе выходят ангидриты и гипсы верхнеиренской подсвиты, а именно лунежской пачки. Она обнажена в разрезах: Чумкасский карьер, д. Залесная, с. Хохловка. В нижней части пачки залегают ангидрит-гипсовые породы от молочно-белого до серого цвета, разнокристаллические, массивные, плотные. В средней части пачки наблюдаются ангидрит-гипсовые породы серого, молочнобелого и голубого цвета, разнокристаллические, неясно-слоистые и массивные, плотные. Верхняя часть представлена ангидрит-гипсовыми породами от серого до молочно-белого цвета, разнокристаллическими, желваковыми и неправильно-слоистыми с тонкими прожилками и прослоями глинисто-карбонатных пород толщиной до 0,4 м, плотными. Глинистокарбонатные породы темно-серые и серые, микротонко-кристаллические, с реликтовой структурой мадстоун и строматолитовый биндстоун (пластовые строматолиты). Мощность пачки от 40 до 66 м [7, 19].

Уфимский ярус подразделяется на соликамский и шешминский горизонты, представленные соответствующими им свитами. Их детальное описание будет представлено далее по тексту. 


\section{Материалы и методика исследования}

В основу работы положены полевые исследования авторов, проводимые с 2005 г., осуществлявшиеся маршрутами вдоль железнодорожных и автомобильных путей; обследовались долины рек, стенки карьеров и горных выработок в центральной части Пермского края. В результате исследований был составлен реестр геологических объектов по уфимскому ярусу, насчитывающий более 60 разрезов, суммарная мощность которых составила 1240 м. Основные типовые разрезы уфимского яруса представлены на (рис. 1, б).

С целью прослеживания глубинного строения отложений уфимского яруса и их литолого-фациальной изменчивости был построен региональный профиль субмеридионального простирания с преобладающим направлением с юго-запада на северо-восток (рис. 1, в). Выбрано шесть поисковых и поисково-разведочных скважин на нефть, обеспеченных данными ГИС, прежде всего кривыми гамма-каротажа (ГК) и нейтронного каротажа (НГК). Скважины Сукманская 35 и Северокамская 184 приурочены, соответственно, к юго-западной и северо-восточной периферийным частям Пермского свода, Шатовская 280 и Тунеговская 169 - к центральной и западной краевой частям Висимской моноклинали.
Скважины Висимская 21 и Белопашнинская 55 пробурены в южной части Соликамской депрессии и расположены на южном замыкании Верхнекамского месторождения калийных солей (ВКМКС). Для литологического расчленения разреза уфимских отложений при интерпретации кривых ГИС использовались также данные по описанию шлама по всему суммарному интервалу их проходки скважинами, составляющему 2018 м. Кроме того, привлекались данные первичного описания керна, попадающие в уфимский интервал в суммарном объеме 511 м. Коррекция стратиграфических границ четвертичных отложений казанского и уфимского ярусов производилась с учетом каталога из дел анализируемых скважин.

Описание геологических разрезов и керна скважин выполнялось снизу вверх, послойно с детальностью, зависящей от степени литологической неоднородности разреза. В результате были выделены литологически контрастные отложения, определен характер залегания и их контакты. Послойный сбор образцов, фауны и флоры проводился из каждого слоя. В результате были составлены коллекции по основным опорным разрезам. Палеонтологические и минералогические находки передавались в геологические и краеведческие музеи.

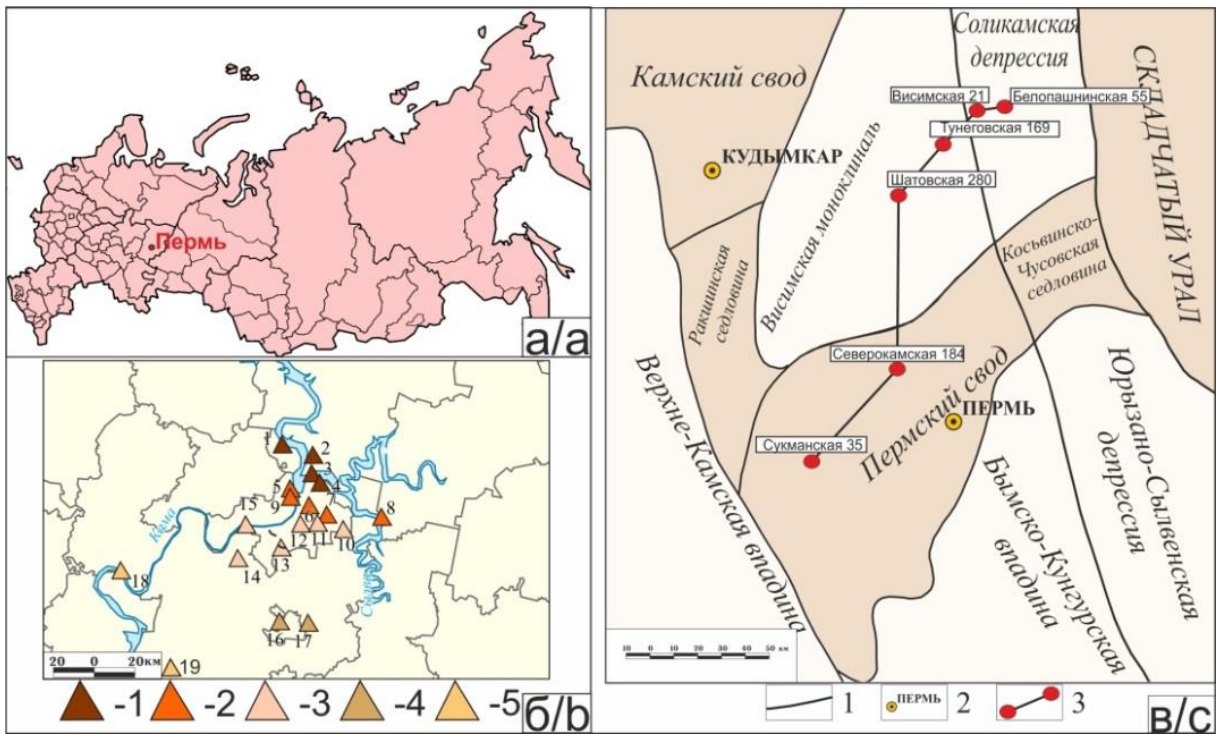

Pис. 1. Местоположение изучаемых разрезов: а) расположение района исследования; б) расположение геологических разрезов. Разрезы: 1 - нижнесоликамской подсвиты; 2 -верхнесоликамской подсвиты; 3 - нижнешешминской подсвиты; 4 - верхнешешлинской подсвиты; 5 - разрезы пограничных отложений уфимского и казанского яруса. Номера геологических разрезов: 1 - с. Хохловка; 2 - Чумкасский карьер, д. Залесная; 3 - «Чусовская стрелка» и карьер «Городище»; 4 - «Банная гора»; 5 - д. Шустовка, д. Турбино; 6 - Резвянский карьер, АЗС «Ликом»; 7 - ст. 30 км ГЖД, ст. Адищево ГЖД; 8 - 54 км ГЖД; 9 - ЖД выемка у Камской ГЭС; 10 - карьер «Протон»; 11 - по р. Ива; 12 - по р. Егошиха; 13 - «Льсая гора»; 14 - «Гляденовская гора»; 15 -«Закамск»; 16 - n. Юг; 17 - п. Звёздный, д. Бершеть; 18 - д. Усть-Нытва; 19 -Оса, д. Пьянково; в) фрагмент тектонической карты Пермского края [7]. 1 - границы тектонических структур; 2 - города; 3 - точки скважин и линия профиля

Fig. 1. Location of the studied sections: a) area; b) geological sections. Sections: 1 -Nizhnesolikamsk subformation; 2 Verkhnesolikamsk subformation; 3 -Nizhnesheshminsk subformation; 4-Verkhnesheshminsk subformation; 5 sections of the boundary deposits of the Ufa and Kazan stages. Geological section numbers: 1 - Khokhlovka village; 2 - Chumkassky quarry, Zalesnaya village; 3 - «Chusovskaya Strelka» and Gorodische quarry; 4 - «Bannaya Gora»; 5 - Shustovka village, Turbino village; 6-Rezvyanskiy quarry, «Likom» gas station; 7 - 30 km railroad station, Adishchevo railroad station; 8 - $54 \mathrm{~km}$ railroad station; 9 - railway excavation at the Kama Hydroelectric Station; 10 - «Proton» quarry; 11 - on the Iva river; 12 - on the Egoshikha river; 13 - "Lysaya Gora»; 14 - "Glyadenovskaya Gora»; 15 - «Zakamsk»; 16 - on the Yug river; 17 -Zvezdny, Bershet villages; 18 - Ust-Nytva village; 19 - Osa, Pyankovo village; c) fragment of the tectonic map of the Perm region [7]. 1 - boundaries of tectonic structures; 2 -cities; 3 - points of boreholes and profile line 
Фациальный анализ основывался на структурнотекстурных и лито-биофациальных наблюдениях, полученных в результате изучения геологических разрезов, кернового материала, а также на данных из опубликованных и фондовых источников с привлечением современной литературы по фациальному анализу [20-23].

Под фацией авторы понимают «горные породы (литотипы), возникшие в определенных условиях осадконакопления определенного геологического времени, представляющие собой конкретный литотип, либо парагенез литотипов, отличающихся от состава и условий образования смежных одновозрастных пород».

Для детального исследования разреза авторами применен секвенс-стратиграфический анализ, нацеленный на выявление и интерпретацию следов колебания уровня моря среди осадочных пород и детальные исследования строения, функционирования и эволюции осадочного палеобассейна на этой основе, освещенный в работах $[20,21,24]$. Введём дополнительные понятия, используемые в данной работе.

Секвенс - это относительно согласная последовательность генетически взаимосвязанных пластов, ограниченная в кровле и подошве стратиграфическими несогласиями или соответствующими им согласными границами. Он сложен последовательностью системных трактов и интерпретируется как геологическое тело, сформированное в период между максимумами падения относительного уровня моря [21]. Системный тракт - это латеральный ряд синхронных седиментационных систем или фаций. Седиментационная система - это трехмерная ассоциация литофаций, генетически связанная осадочными обстановками, к примеру: дельта, река, лагуна, барьерный остров, шельф и т. д. [21]. Системный тракт охарактеризован положением внутри секвенса, различным типом пакетов парасеквенсов, определенной геометрией отражающих поверхностей на сейсмопрофилях. Формирование системного тракта связано с определенным положением уровня моря. Это отражено в их названиях: тракт низкого стояния (ТНС), трансгрессивный системный тракт (ТСТ), тракт высокого стояния (ТВС).

\section{Результаты исследования геологических разрезов}

Авторами были обобщены все предшествующие известные данные и сопоставлены с вновь полученными результатами проведенной работы. За основу была взята работа А.С. Сунцева [13] по литологическому разделению на пачки. Далее по тексту приведена вещественная характеристика подсвит с применением классификации структур Р. Данхэма [25]. Сoставлен сводный разрез уфимского яруса (рис. 2).

Соликамская свита подразделяется на две подсвиты: нижнюю сульфатно-карбонатную и верхнюю глинисто-терригенную. Нижнесоликамская подсви$m a-$ в районе исследования приурочена к сульфатнокарбонатному типу разреза, литологически подразделена на пять пачек (снизу-вверх): доломитовая, суль- фатно-мергельно-доломитовая, мергельно-доломитовоизвестняковая, песчано-мергельно-доломитовоизвестняковая и глинисто-известняковая. Мощность подсвиты изменяется от 110 до 120 м, увеличиваясь на север (рис. 2).

Доломитовая пачка. Доломиты преимущественно светло-серые, разнокристаллические, со структурами доломадстоун, вакстоун, пакстоун, грейнстоун и строматолитовый баундстоун (биндстоуны и фреймстоуны); мелко- и тонкослоистые, в баундстоунах органогенно-слоистые, с линзами молочного селенита и желваками ангидрита, крепкие. Органические остатки: разнообразной морфологии строматолиты, раковины пелеципод, остракоды, минерализованная древесина (рис. 3, а, б). Данная пачка изучена в разрезах с. Хохловка, Чумкасском карьере и д. Залесной. Мощность пачки изменяется от 8 до 10 м.

Сульфатно-мергельно-доломитовая пачка представлена сульфатизированными доломитами и мергелями с прослоями алевролитов и сульфатов. Доломиты серые, тонко- и мелкокристаллические, с несохранившейся первичной структурой, с единичными прослоями реликтовых строматолитовых биндстоунов, тонко и средне-слоистые, прослоями брекчированные; с желваками и линзами гипса и ангидрита, реже кальцита; с трещинами, крепкие. Мергели глинистые, темно-серые, доломитистые, микрокристаллические, тонко- и микро-слоистые, плитчатые, с включениями и стяжениями ангидрита, крепкие. На поверхности напластования доломитов и мергелей иногда встречаются глиптоморфозы по кристаллам соли, сростки линзовидных кристаллов (розеток) ангидрита и трещины усыхания (рис. $4, a, \sigma)$.

К очень большому сожалению, в очерке, посвященном соликамским отложениям Чумкасского карьера (левобережье р. Камы в 7 км выше устья р. Чусовой; Пермский край), изображенные отпечатки сростков кристаллов гипса названы «кристаллами льда», причем эта подпись была составлена редактором книги [9. С. 187] без согласования с автором очерка С.В. Наугольных, который в устном сообщении твердо подчеркнул, что на фото изображены именно кристаллы гипса, а также отпечатки таких кристаллов и псевдоморфозы по кристаллам гипса, что и было обозначено в оригинальной авторской подписи к фотографии.

Алевролиты коричневато- и темно-серые, микрослоистые, известковистые, плотные, с включениями желваков и кристаллов ангидрита, гипса с единичными «гипсовыми розами» (рис. 4, в). Сульфатная часть разреза имеет текстурную цикличность снизу вверх: шевронная $\rightarrow$ массивная желваковая $\rightarrow$ линзовидножелваковая $\rightarrow$ брекчиевидная хаотическая. Органические остатки: единичные остракоды и пластовые строматолиты. Пачка изучена в Чумкасском карьере, д. Залесной и на Чусовской стрелке. Мощность колеблется от 4 до 5 м, увеличиваясь на север до 50 м, за счет появления в разрезе многометровой толщи циклически построенных сульфатов. 


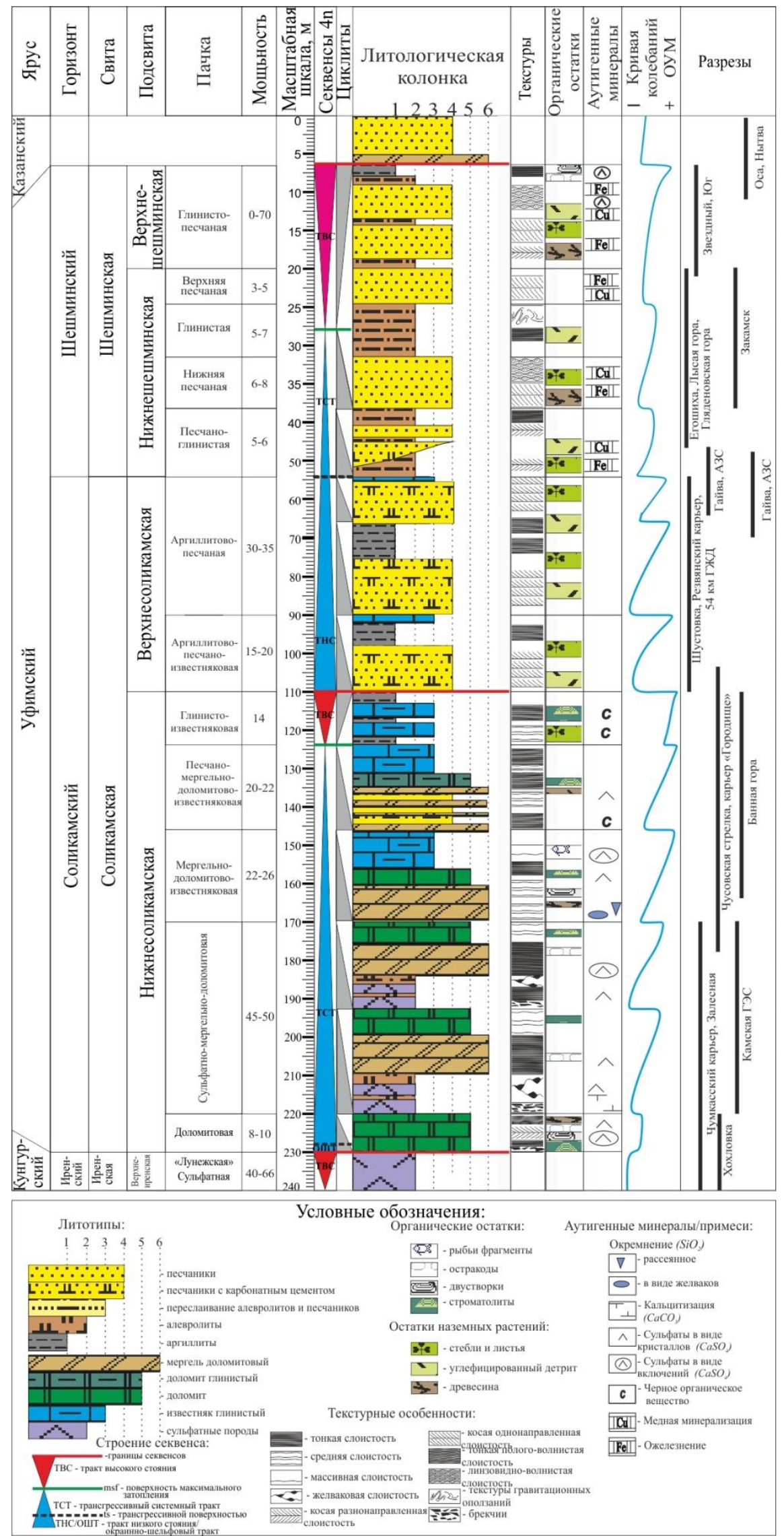

Pис. 2. Сводный геологический разрез уфимского яруса востока Восточно-Европейской платформы иентральной части Пермского края, составленный по результатам изучения обнажений

Fig. 2. Consolidated geological section of the Ufa stage in the east of the East European platform in the central part of the Perm Territory compiled based on the results of the sections study 

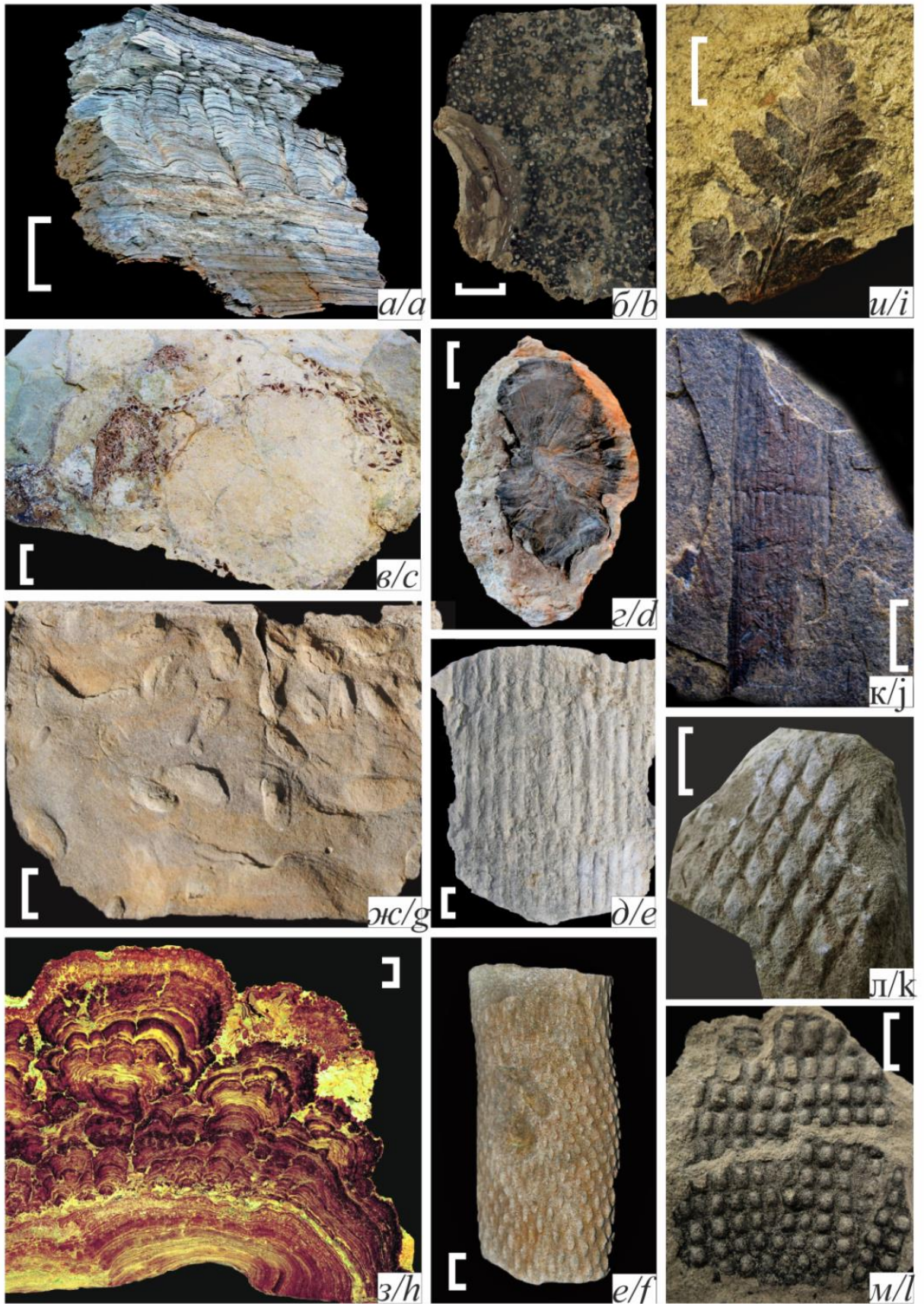

Рис. 3. Палеонтологические находки из соликамской свиты: а) вертикальное изменение морфологии строматолитов от пластовых до столбчатых и желваковых в толще доломитов и мергелей; б) фрагмент минерализованной древесины Dadoxylon sp. на оолитовом грейнстоуне; в) фрагменты чешуи рыбы рассеянной в породе; 2) минерализованная древесина Dadoxylon sp.; д) фрагмент ствола иленистостебельного Calamites gigas Brongniart; e) побег древовидного плауновидного Viatcheslavia vorcutensis Zalessky; ж) скопление раковин двустворок; з) столбчатый строматолит Alebastrophyton sylvense Naugolnykh et Litvinova; u) фрагмент листа папоротника Pecopteris sp.; к) фрагмент побега членистостебельного Paracalamites sp.; л) отпечаток ствола хвойного; м) нижняя часть побега членистостебельного Paracalamitina sp. Местонахождения: $a, 6,2$, д. Залесная; б-с. Хохловка; д, е, л-с. Троица; м-ст. Алебастрово; ж, и, м-ст. 54 км ГЖД; л-долина p. Васильевка. Длина масштабных линеек: $a-1$ м; б-м-1 см

Fig. 3. Paleontological finds from the Solikamsk formation: a) vertical change in the morphology of stromatolites from bedded to columnar and nodular in the stratum of dolomites and marls; b) a fragment of mineralized wood Dadoxylon sp. on oolitic grainstone; c) fragments of fish scales scattered in the breed; d) mineralized wood Dadoxylon sp.; e) a fragment of the inner cast of a very large trunk of Calamites gigas Brongniart; f) fragment lycopsid Viatcheslavia vorcutensis Zalessky; g) cluster of bivalve shells; h) column-type stromatolites Alebastrophyton sylvensis Naugolnykh et Litvinova; i) leaf of ferns Pecopteris sp.; j) fragment of trunk of Paracalamites sp.; $k$ ) decorticated conifer stem; l) fragment of the lower part of the trunk Paracalamitina sp. Locations: $a, c, d$-Zalesnaya village; $b$-Khokhlovka village; $e, f, i$-Troitsa village; $l$-Alebastrovo railroad station; $g, h, j-s t .54 \mathrm{~km}$ railroad station; $k$-valley of the Vasilyevka river. Scale bar is $1 \mathrm{~m}(a)$ and $1 \mathrm{~cm}(b-l)$ 
Мергельно-доломитово-известняковая пачка сложена преимущественно известняками с прослоями доломитов, мергелей, алевро-песчаных пород. Известняки неравномерно глинистые, серые; со структурой мадстоун и вакстоун; массивные и тонкослоистые, с сульфатными и кальцитовыми стяжениями, с редкими желваками кремня, участками слабо битуминозные, плотные. Доломиты и мергели, с несохранившейся первичной структурой, идентичны вышеописанным, за исключением отсутствия сульфатизации. В верхней части разреза в известняках наблюдаются прослои алевролитов мелко-крупнозернистых и песчаников мелко-тонкозернистых, неясно-слоистых.

Органические остатки: единичные пелециподы, фрагменты минерализованной древесины, чешуя рыб, единичные пластовые строматолиты (рис. 3, в, г). Пачку можно наблюдать в д. Залесной и в районе мыса Стрелка. Мощность пачки изменяется от 22 до 26 м.

Песчано-мергельно-доломитово-известняковая пачка представлена переслаиванием мергелей с тонкими прослоями песчаников, доломитов и известняков. Известняки глинистые, серые, со структурой мадстоун, тонко- и средне-слоистые, слабо битуминозные, крепкие. Доломиты глинистые, светло-серые, тонкомелкокристаллические с несохранившейся первичной структурой, с единичными прослоями реликтовой микробиальной структуры строматолитовый биндстоун, средне-слоистые, крепкие. Мергели доломитистые, светло-серые, тонко-микрокристаллические, с примесью терригенного материала, реже с прослоями тонкозернистого песчаника, тонко- и средне-слоистые, с желваками и прослоями ангидрита и гипса, крепкие.

На поверхности напластования доломитов и мергелей иногда встречаются глиптоморфозы по кристаллам соли, включения кристаллов ангидрита и волноприбойные знаки, образующие широкие плитки на первой надпойменной террасе р. Сылва в районе с. Троица (рис. 4, 2-3). Органические остатки: единичные находки минерализованной древесины, пластовые строматолиты (рис. 3, ж-u). Пачка изучена в карьере «Городище» и с. Троица. Мощность пачки изменяется от 20 до 22 м.

Глинисто-известняковая пачка сложена известняками с прослоями аргиллитов. Известняки темносерые, со структурой мадстоун, средне- и крупнослоистые, трещиноватые, битуминозные, крепкие. На поверхности напластования встречаются следы ползания двустворок (рис. 4, u). Аргиллиты алевритистые зеленовато-серые, тонко- и листовато-слоистые, хрупкие. Пачка изучена в карьере «Городище» и на ст. 54 км ГЖД. Мощность пачки составляет 14 м.

Таким образом, изученные пачки (снизу верх) свидетельствуют об аридном климате, общей трансгрессии и углублении раннесоликамского бассейна.

Верхнесоликамская подсвита. Граница между нижнесоликамской и верхнесоликамской подсвитами проводится по подошве песчаников в Городищенском карьере и в обнажении «54 км ГЖД». Подсвита состоит из двух пачек: аргиллитово-песчано-известняковой и аргиллитово-песчаной (рис. 2). Мощность верхнесоликамской подсвиты порядка 50-55 м.
Аргиллитово-песчано-известняковая пачка представляет собой чередование известняков, аргиллитов и песчаников с редкими прослоями алевролитов. Известняки доломитизированные, серые от светло- до темно-серых, со структурой мадстоун, тонко- и средне-слоистые, плотные. Аргиллиты красноватосерые до серых, тонкослоистые, хрупкие. Алевролиты глинистые, коричневато-бурые, реже с зеленоватым оттенком, мелкозернистые, тонкослоистые, хрупкие. Песчаники зеленовато-серые, полимиктовые, мелкозернистые, известковистые, косослоистые, крепкие. Органические остатки: фрагменты растений (рис. 3, u, к). Слои пачки описаны в верхней части Городищенского карьера, в обнажениях «Шустовка», «Пальники», «Банная гора» и «54 км ГЖД». Мощность пачки - от 15 до 20 м.

Аргиллитово-песчаная пачка. Пачка сложена в основном песчаниками и аргиллитами с прослоями алевролитов и тонкими пропластками известняков. Песчаники серые, зеленовато-серые, разнозернистые, нормально- и косослоистые, крепкие. Аргиллиты темно-серые, бурые, тонкослоистые, хрупкие. Алевролиты известковистые, серые, мелкокрупнозернистые, тонкослоистые, хрупкие. Органические остатки: обуглившиеся фрагменты растений (рис. 3, м). Пачка описана в долине р. Васильевки, Резвянском карьере и железнодорожной выемке микрорайона Гайва. Мощность пачки - 30-35 м.

Шешминская свита подразделяется на две подсвиты: нижнюю глинисто-песчаную и верхнюю песчаную. Мощность свиты достигает 220 м (рис. 2).

Нижнешешминская подсвита состоит из четырех пачек (снизу вверх): песчано-глинистая, мощностью около 6 м; нижняя песчаная, мощностью 8 м; глинистая, мощностью 7 м; верхняя песчаная, мощностью 5 м. Выделение пачек произведено на основе изучения обнажений, расположенных в долинах рек Кама, Егошиха, Мулянка, Ива, Таложанка и карьере «Протон», описанных в публикациях [16, 27, 28]. Суммарная мощность пород подсвиты составляет 24 м. Вся мощность нижнешешминской подсвиты в пределах территории достигает 150 м [9].

Песчаники зеленовато- и реже буровато-серые, мелко-среднезернистые, с карбонатным и глинистым цементом, субгоризонтально- и косослоистые, от слабо до сильно сцементированных. В основании песчаниковых тел спорадически встречаются мелкие линзы гравелитов и конгломератов с гальками аргиллитов, алевролитов и уральских магматических пород. Алевролиты коричневые и буровато-серые, мелкокрупнозернистые с примесью мелкозернистого песчаного материала, с карбонатным цементом, тонкослоистые, хрупкие. Аргиллиты темно-коричневые, красновато-коричневые, прослоями до аргиллитов алевритистых, микро-слоистые, хрупкие. Переход в верхнешешминскую подсвиту постепенный. Контакт проводится по появлению красновато-серых разнозернистых песчаников с косой разнонаправленной слоистостью и прослоев алевролитов. 

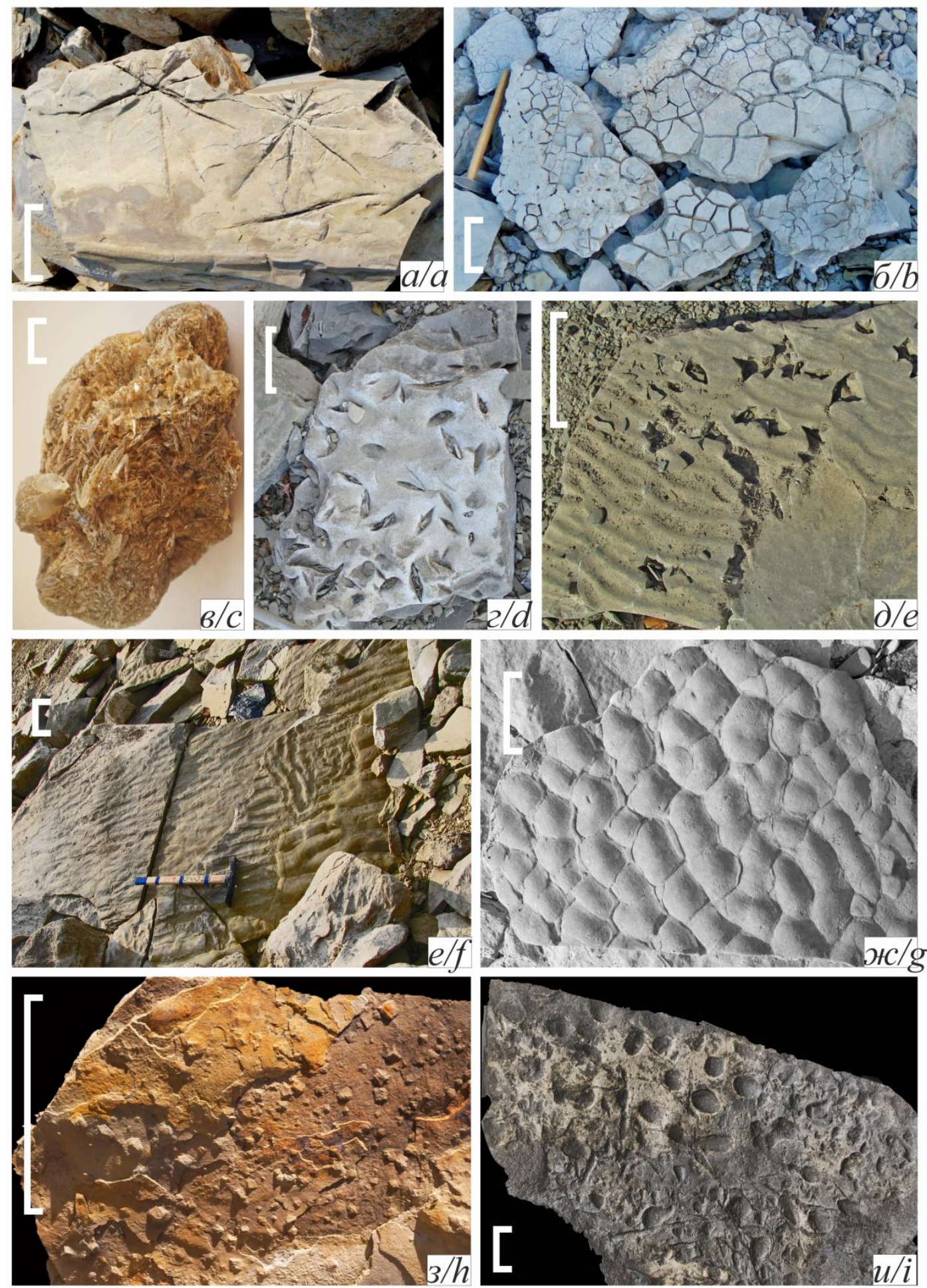

Рис. 4. Литологические находки из соликамской свиты: а) лучистые сростки кристаллов ангидрита в мергеле; б) трещчины усыхания в мергеле; в) сростки кристаллов гипса «гипсовая роза»; г) выщелоченные кристалль гипса в мергеле; д) выщелоченные кристаллы гипса на поверхности волновой ряби; е) волновая рябь на алевритистом песчанике; ж) перекрѐстная рябь; з) глиптоморфозы илистого осадка по кубам каменной соли; и) следы ползания беспозвоночных (двустворок, ихнород Lockeia [26]) с внутренними отливами их ядер. Mестонахождения: $а$, б, г) д. Залесная; д) “Чусовская стрелка»; е) Троища; ж) ст. Алебастрово ГЖД; з, и) ст. 54 км ГЖД. Длина масштабных линеек: а, б, г-з) 10 см; в, и) 1 см

Fig. 4. Lithological finds from the Solikamsk formation: a) radiant intergrowths of anhydrite crystals in marl; $b$ ) drying cracks in marl; c) intergrowths of gypsum crystals "gypsum rose»; d) leached crystals of gypsum in marl; e) leached gypsum crystals on the surface of wave ripples; $f$ ) wave ripples on silty sandstone; $g$ ) cross ripple; $h$ ) gliptomorphosis of silty sediment over cubes of rock salt; $i$ ) traces of crawling invertebrates (bivalves, ichinogen Lockeia [26]) with internal ebbs of their nuclei. Locations: $a, b, d) v$. Zalesnaya; e) Chusovskaya Strelka; f) Troitsa; $g$ ) st. Alabastrovo; $h, i)$ st. $54 \mathrm{~km}$ railroad station. Scale bar is $10 \mathrm{~cm}(a, b, d-h)$ and $1 \mathrm{~cm}(c, i)$ 
Верхнешешминская подсвита представлена глинисто-песчаной пачкой. Песчаники красноватосерые, разнозернистые, хорошо отсортированные, с карбонатным цементом, с косой, косой разнонаправленной и линзовидно-волнистой слоистостью, плотные. Залегают песчаники в виде довольно мощных линзовидных тел среди красноцветных горизонтально-слоистых аргиллитов и алевролитов. Мощность верхнешешминской подсвиты достигает 70 м. Верхнешешминская подсвита хорошо обнажена в карьере и старых медных шахтах в П. Юг, а также в карьерах вблизи п. Звёздный и в обнажении на Сибирском тракте у с. Бершеть.

В красноцветных отложениях шешминского горизонта встречаются остатки пресноводных пелеципод, остракод, рыб, остатки наземных позвоночных, а также большое количество растительных остатков в виде окаменелых и обуглившихся стволов деревьев, небольших стеблей и листьев, а также единичные находки следов ползанья членистоногих (рис. 5, $a-8$ ).

В Пермском крае к отложениям шешминской свиты приурочены многочисленные проявления меди медистые песчаники. Залежи медных руд залегают линзообразно или гнездообразно и многоуровнево. Все медьсодержащие минералы медистых песчаников по генетическим признакам делятся на две группы: первичные - сульфиды, самородная медь, и вторичные - водные карбонаты меди. К первой группе относятся халькопирит, халькозин, ковеллин и др. Ко второй относится малахит и азурит. Малахит развивается исключительно за счет первичных сульфидов меди и образует конкреции, плотные скопления и рассеянную вкрапленность, а чаще всего налеты, пленки и корочки (рис. 5, г-e). Азурит, будучи постоянным спутником малахита, значительно уступает ему в степени распространения. Формы проявления азурита те же, что и у малахита. Авторами отмечается значительная приуроченность аутогенных минералов меди к скоплению растительных остатков, которые выступали своего рода геохимическим барьером, способствующим минералообразованию.

Отложения шешминской свиты согласно перекрываются терригенными породами казанского яруса. Границу их можно наблюдать вблизи города Оса и п. Усть-Нытва.

Освещенное строение пачек терригеннокарбонатного типа разреза соликамской свиты и терригенный тип разреза шешминской свиты показывает особенности осадконакопления центральной части Пермского края района города Перми.

\section{Результаты региональной скважинной корреляции}

Исследование по региональной скважинной корреляции ввиду разноранговости региональных и детальных наблюдений не ставит перед собой задачи отображения литологической цикличности, выявленной на локальном литотипном участке, а лишь дополняет представление о пространственной литофациальной изменчивости разреза уфимского яруса в Пермском Прикамье.

Анализ целесообразно начать со скважины Белопашнинская 55-ОГН, расположенной в надсолевой зоне ВКМКС, поскольку данные литологической интерпретации сопряжены здесь с описанием керна. Отложения соликамской свиты залегают на покровной каменной соли лунежской пачки иренской свиты кунгурского яруса (рис. 1, С; 6).

Нижнесоликамская подсвита выделяется в объеме соляно-мергельной пачки мощностью 101,5 м. Соляно-мергельные отложения в своем основании сложены базальной переходной пачкой каменной соли с ритмично залегающими прослоями глин, мощностью 18,2 м. Выше по разрезу залегают мергели, преимущественно доломитового состава, с редкими прослоями каменной соли толщиной 1,0-1,5 м, в кровле известняки с прослойками гипса.

Верхнесоликамская подсвита представлена терригенно-карбонатной пачкой мощностью 106,4 м. Нижняя часть пачки сложена различными известняками с тонкими прослойками гипса и глин, а верхняя прикровельная часть - чередованием песчаников, глин, алевролитов и доломитов.

Шешминская свита сложена пестроцветной толщей, представленной чередованием песчаников, алевролитов и аргиллитов. В данном разрезе нижняя и верхняя части не выделены.

Таким образом, разрез уфимских отложений по этой скважине характеризует особенности строения надсолевой толщи с признаками затухающего галокинеза в её нижней части и замены сульфатнокарбонатных-глинистых фаций на прибрежноконтинентальные терригенные.

Скважина Висимская 21 находится в 8 км западнее скважины Белопашнинская 55-ОГН. Строение уфимского разреза данной скважины связано с её расположением в своде иренского соляного поднятия. Вследствие этого пестроцветные отложения шешминской свиты подверглись эрозии и полностью отсутствуют в разрезе.

Нижнесоликамская подсвита мощностью 65 м залегает на иренской покровной каменной соли. В отличие от предыдущего разреза, она характеризуется мергельным составом без прослоев каменной соли и переходной пачки. Сложена переслаиванием мергелей, доломитов, наблюдаются тонкие прослои гипса.

Верхнесоликамская подсвита мощностью 106 м представлена классической терригенно-карбонатной пачкой: нижняя карбонатная часть (71 м) сложена известняками с прослоями мергелей и глин, верхняя терригенная (35 м) - чередованием песчаников, алевролитов и аргиллитов.

Скважина Тунеговская 169 расположена на условной границе Соликамской депрессии и Висимской моноклинали, в 14 км юго-западнее скважины Висимская 21. Мощность уфимского яруса составляет 402,2 м. Уфимские отложения представлены полным типом разреза: нижнесоликамской и верхнесоликамской подсвитами, нижней и верхней подсвитами шешминской свиты.

Нижнесоликамская подсвита мощностью 64 м также синхронизируется с соляно-мергельной толщей, поскольку в верхней её части выделяется прослой каменной соли толщиной 3,2 м. 

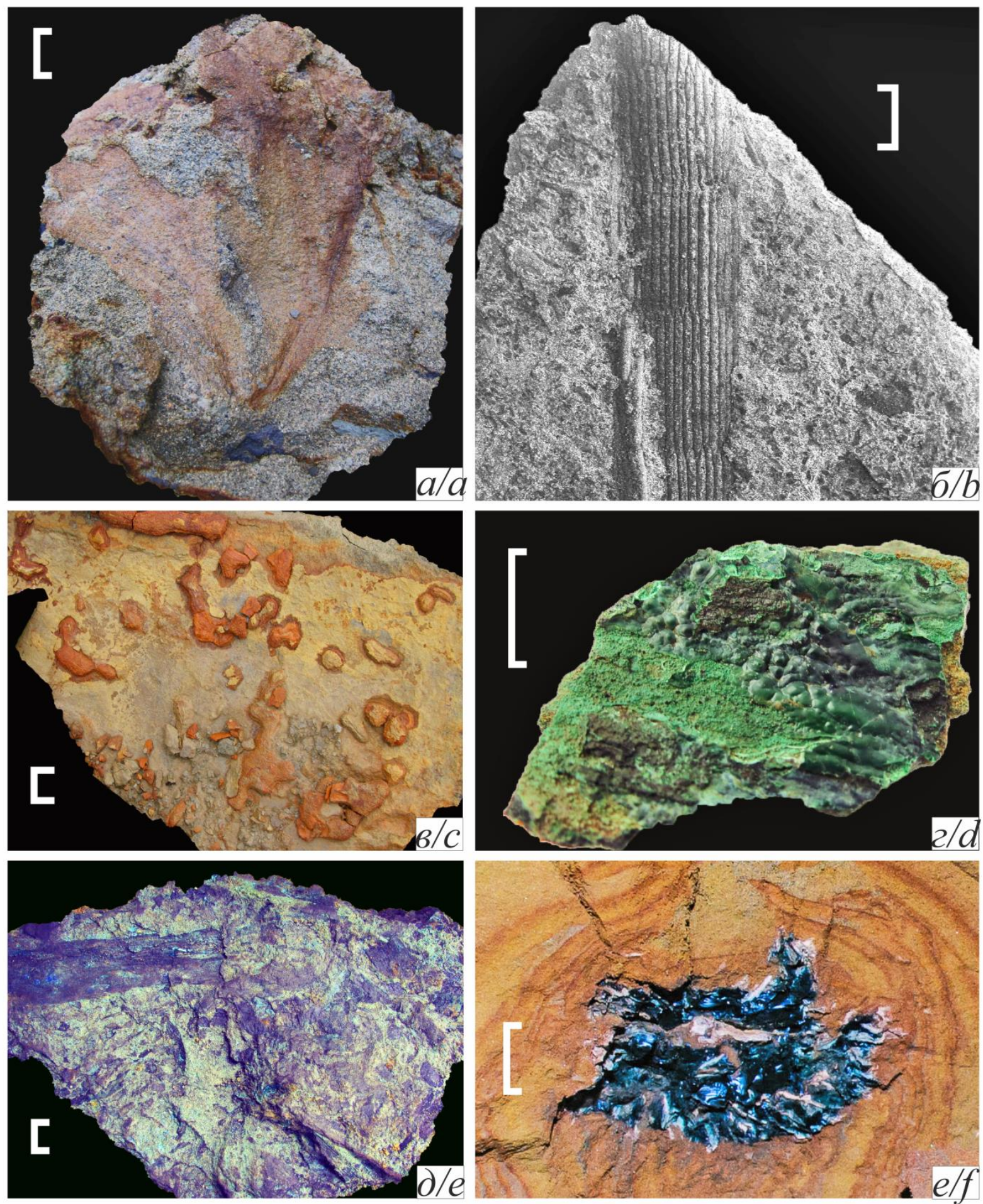

Pис. 5. Палеонтологические и литологические находки из шешминской свиты: a) отпечаток листа Psygmophyllum expansum (Brongniart); б) отпечаток побега членистостебельного Paracalamitina sp.; в) следы ползания членистоногих рачков на поверхности песчаника; г) минерализованная натечными осадочными минералами меди древесина; д) растительные остатки, инкрустированные минералами меди: малахитом и азуритом; е) минерализованный минералами меди ствол в стенке карьера. Местонахождения: а, в-е) карьер Протон;

б) Автодорожная выемка юго-востока г. Перми. Длина масштабной линейки 1 cм

Fig. 5. Paleontological and lithological findings of the Sheshminskaya suite: a) leaf imprint of Psygmophyllum expansum Brongniart; b) print of the shoot of the arthropod Paracalamitina sp.; c) traces of crawling arthropods on the surface of sandstone; d) wood mineralized by drip sedimentary minerals of copper; e) plant remains inlaid with copper minerals: malachite and azurite; f) shaft mineralized with copper minerals in the wall of the quarry. Locations: $a, c-f)$ Proton quarry; b) Road excavation in the south-east of Perm. Scale bar is $1 \mathrm{~cm}$ 


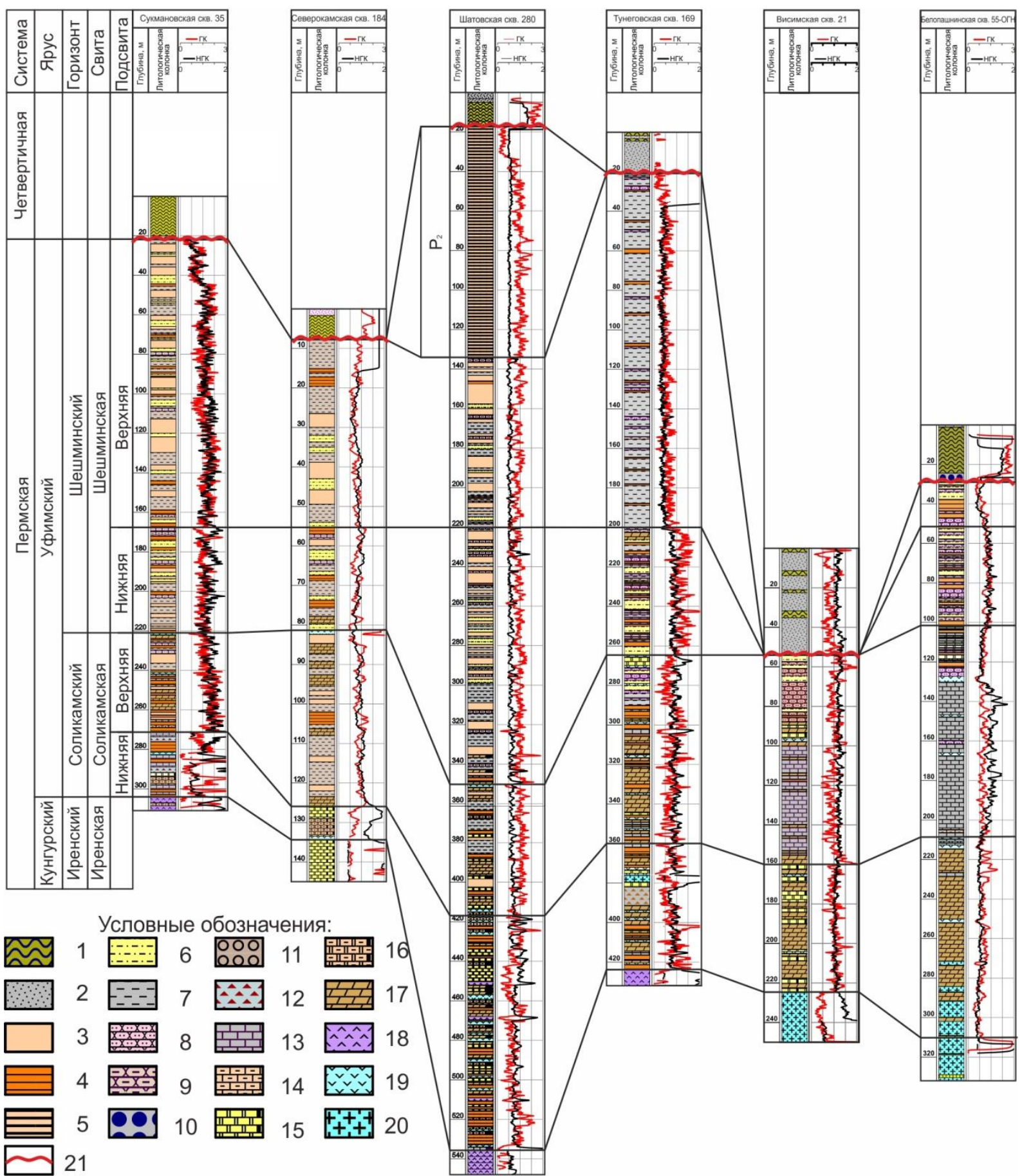

Рис. 6. Региональный субмеридиональный профиль, показывающий смену типов разреза уфимского яруса по площзади. Условные обозначения: 1) суглинки; 2) мелкозернистый песок; 3) глина алевролитистая; 4) глина и аргиллит; 5) мергельно-глинистая порода; 6) алевролит; 7) алевролит глинистый; 8) песчаник; 9) песчаник глинистый; 10) галечник; 11) конгломерат; 12) известняковая брекчия; 13) известняк плотный; 14) известняк глинистый; 15) доломит; 16) доломит глинистый; 17) мергель; 18) ангидритовая порода; 19) гипсовая порода; 20) каменная соль и засолонение; 21) поверхность эрозионного размыва

Fig. 6. Regional longitudional profile showing the change in the types of the Ufa stage over the area. Legend: 1) loam; 2) fine-grained sand; 3) silty clay; 4) clay and mudstone; 5) marl-clay rock; 6) siltstone; 7) clayey siltstone; 8) sandstone; 9) clayey sandstone; 10) pebble; 11) conglomerate; 12) limestone breccia; 13) dense limestone; 14) clayey limestone; 15) dolomite; 16) clayey dolomite; 17) marl; 18) anhydrite rock; 19) gypsum rock; 20) rock salt and salinization; 21) erosional surface

Верхнесоликамская подсвита мощностью 94,4 также сложена терригенно-карбонатной пачкой в соотношении 2/3 (карбонаты), 1/3 - терригенная часть. Нижняя карбонатная часть представлена чередовани- ем мергелей, известняков, доломитов и аргиллитов, верхняя сложена переслаиванием песчаников, алевролитов, аргиллитов с прослоями доломита. 
Нижнешешминская подсвита представлена хорошо дифференцированным тонкослойным переслаиванием песчаников, алевролитов, и аргиллитов. В кровле свиты выделяется мергель и глинистый песчаник.

Верхнешешминская подсвита сложена большей частью глинистыми алевролитами с редкими прослоями песчаников и аргиллитов.

Скважина Шатовская 280 пробурена в центральной части Висимской моноклинали, в 33 км к югозападу от скважины Тунеговская 169. Отложения уфимского яруса здесь перекрыты 118-метровой толщей глинистых пород казанского яруса.

Нижнесоликамская подсвита (118 м) подразделяется на несколько литологических пачек. В целом подсвита характеризуется сульфатно-карбонатноглинистым составом. Снизу вверх последовательно залегают карбонатно-глинистая, мергельносульфатно-карбонатная, доломитовая пачки, а в верхней части и кровле - сульфатно-карбонатноглинистая пачка.

Верхнесоликамская подсвита (мощность 67 м) в нижней части подразделяется на карбонатномергельную пачку, а в верхней - на карбонатноглинисто-алевролитовую

Нижнешешминская подсвита вверх по разрезу представлена чередованием песчаниково-глинистоалевролитовой, глинисто-алевролитовой, а верхней части - алевролитово- песчаниковой пачек. Мощность подсвиты $130 \mathrm{м}$.

Верхнешешминская подсвита (85 м) условно подразделяется вверх по разрезу на две пачки. Нижняя сложена переслаиванием алевролитов, в различной степени глинистых, верхняя - чередованием алевролитов, алевролитистых глин и песчаников.

Скважина Северокамская 184 расположена в центральной части Пермского свода, на северовосточном окончании Краснокамско-Полазненского вала, в 77 км южнее предыдущей скважины Шатовская 280. Тип разреза уфимских отложений имеет здесь сводовый характер, с сокращенной мощностью 126 м. При этом стратиграфическая полнота сохранена, выделяются все стратиграфические подразделения уфимского яруса.

Нижнесоликамская подсвита $(8,3$ м) залегает на иренских доломитах, четко выделяется по каротажу, в виде глинисто-доломитовой пачки (внизу глинистые доломиты, выше - чистые доломиты). В подошве залегает слой гипса толщиной 1 м.

Верхнесоликамская подсвита (41,7 м) характеризуется карбонатно-терригенным типом разреза. В нижней, 18-метровой, части залегают алевролиты с различной степенью глинистости, в подошве - пласт мергеля. Выше по разрезу наблюдается чередование мергелей, глин, алевролитов.

Нижнешешминская подсвита (29,2 м). В нижней части разреза представлена пачкой алевролитов, переслаивающихся с аргиллитами. В верхней части разреза наблюдается чередование аргиллитов, алевролитов и песчаников.

Верхнешешминская подсвита (47,4 м) подразделяется вверх по разрезу на две пачки. Нижняя сложена переслаиванием алевролитов, различной степени глинистых, верхняя - чередованием алевролитов глинистых и аргиллитов.

Скважина Сукманская 35 находится на югозападном замыкании Краснокамско-Полазненского вала Пермского свода, в 60 км юго-западнее скважины Северокамская 184.

Нижнесоликамская подсвита (33 м) характеризуется уменьшенной мощностью из-за стратиграфических перерывов в ходе ее седиментогенеза. Нижняя часть подсвиты сложена в основании переслаиванием известняков и аргиллитов, а выше - доломитами. Верхняя часть подсвиты имеет глинистоизвестняковый состав с зонами карбонатной брекчии.

Верхнесоликамская подсвита (50 м) представлена карбонатно-терригенным типом разреза. В нижней части подсвиты выделяется карбонатно-глинистая пачка, сложенная переслаиванием аргиллитов, доломитов и мергелей. Выше - терригенная пачка, представленная чередованием аргиллитов, песчаников и алевролитов.

Нижнешешминская подсвита $(53,4$ м). Нижняя часть подсвиты мощностью 25 м сложена глинистыми алевролитами с прослоями аргиллитов. Верхняя ее часть представлена чередованием песчаников, аргиллитов и алевролитов.

Верхнешешминская подсвита. Имеет для этого разреза увеличенную мощность (146 м) и пестрый литологический состав. В основании подсвиты залегают аргиллиты, алевролиты и песчаники. Выше по разрезу прослеживается 80-метровая толща, сложенная глинистыми алевролитами и алевролитистыми глинами с прослоями песчаника.

Выводы

1. Разрез уфимского яруса надсолевой толщи Соликамской депрессии характеризует особенности соляной тектоники этой зоны: наличие прослоев солей в нижней части соликамских отложений в мульдах и на склонах иренской соляной толщи и отсутствие таковых в сводах соляных поднятий. В целом строение надсолевой нижнесоликамской толщи отражает затухание признаков галокинеза вверх по разрезу. В сводах соляных поднятий наблюдается сокращенный (неполный) тип разреза уфимского яруса вследствие эрозии шешминских и верхнесоликамских отложений.

2. В переходных от лагунных типов разреза к прибрежно-мелководным нижнесоликамские отложения представлены мергельно-глинистой толщей, а верхнесоликамские - терригенно-карбонатными и карбонатно-терригенными фациями. Пестроцветные отложения шешминской свиты занимают уже больший мощностной интервал в объеме уфимского яруса, чем соликамские.

3. Непосредственно над соляными поднятиями, а также в зонах тектонических валов и сводовых вершин наблюдается сокращенный (сводовый) тип разреза уфимской свиты, где ее мощность уменьшается до 126 м. 
4. В сводовых разрезах мощность нижнесоликамской свиты сокращена из-за наличия стратиграфических перерывов в ходе седиментогенеза, когда осушенные участки подвергались наземной эрозии. Об этом свидетельствует наличие зон внутриформационной карбонатной брекчии в разрезах нижнесоликамской подсвиты (Сукманская скв. 35, Тунеговская скв. 169).

5. В зоне развития платформенных фаций, по мере удаления скважин профиля на юго-запад, доминирующим типом разреза верхнесоликамской подсвиты является терригенно-карбонатный. Однако эта закономерность нарушается в зонах развития супралиторальных фаций, когда и нижняя карбонатная часть замещена глинистыми алевролитами и глинами алевролитистыми (скв. 184).

6. В ещё большей мере характерно преобладание озёрных фаций для шешминской свиты на югозападе профиля (скв. 35, 184, 280). Разрез верхнешешминской подсвиты по Тунеговской скв. 169 мощностью 178,7 м полностью сложен супралиторальными фациями: глинистыми алевролитами, глинами алевролитовыми с редкими прослоями аргиллитов.

Таким образом, уфимские отложения в центральной и северо-восточной частях Пермского края отличаются большим литолого-фациальным разнообразием и изменчивостью, обусловленными как палеогеоморфологическими и тектоническими условиями уфимского века, так и особенностями их формирования в ходе седиментогенеза.

\section{Фациальный анализ отложений соликамской свиты}

Результаты фациального анализа, исследования литологического состава пород и состава макрофоссилий позволили отнести отложения нижнесоликамской подсвиты к группе открытого шельфа и изолированного шельфа (лагуны) эпиконтинентального бассейна (рис. 7, а), а породы верхнесоликамской подсвиты относятся к группе осадков приливноотливной терригенной отмели (рис. 7, в). Далее по тексту авторы приводят описание диагностированных в разрезе фаций.

Открытый шельф. Относительно глубокая сублитораль. Фация представлена микрослоистыми известковистыми аргиллитами, микрокристаллическими известняками (мадстоунами) с прослоями аргиллитов, породами битуминизированными, с характерным запахом сероводорода при раскалывании породы Из органических остатков встречены лишь фрагменты рыб. Осадконакопление происходило в условиях слабой и весьма слабой гидродинамики, относительно больших глубин (более 30 м), нормальной солености при привносе глинистого материала, иногда придонной аноксии [29-31].

Сублиторали со спокойной придонной гидродинамикой вод. Фация представлена известняками, доломитами и мергелями со структурой мадстоун и вакстоун, неправильно- и тонко-микрослоистыми. Из органических остатков встречаются остракоды и редкие фрагменты рыб. Осадконакопление происходило в условиях спокойной гидродинамики, иногда доходя до застойных вод, нормальной солёности, на умеренных глубинах ниже базиса нормальных волн [32].

Сублиторали с активной придонной гидродинамикой вод. Фация представлена известняками и доломитами со структурами пакстоун и оолитовый грейнстоун, со слабозаметной мелкой косой и косой разнонаправленной слоистостью. Из органических остатков встречаются угловато-окатанные фрагменты древесины, пелециподы. Осадконакопление происходило в условиях умеренной и активной гидродинамики, нормальной солёности, на незначительных глубинах

Карбонатная литораль. Фация представлена доломитами двух структурных типов: микробиальными строматолитовыми биндстоунами, фреймстоунами и мадстоунами. Карбонатная литораль по типу строматолитов подразделена на нижнюю литораль - доломиты с крупно-столбчатыми и желваковыми строматолитовыми фреймстоунами, и верхнюю - доломиты с пластовыми строматолитами структуры биндстоун. Для пород характерна органогенная слойчатость, иногда с желваками ангидрита. Мадстоуны литорали тонкослоистые, микрокристаллические. Для верхней литорали характерны трещины усыхания, глиптоморфозы и более интенсивная сульфатизация. Из органических остатков встречаются остракоды, пелециподы, фрагменты стволов и отпечатки листьев растений. Отличительной особенностью баундстоунов (фреймстоунов) является постепенный переход от крупно-желваковых к крупно- и мелко-столбчатым формам, что связано с регрессией и выходом в супралиторальные условия. Формирование осадков происходило в условиях крайнего мелководья, при периодических суточных колебаниях уровня моря, с периодически меняющейся соленостью [33-35].

Береговая себха. Фация представлена желваковыми ангидритами с разнообразными реликтовыми включениями доломитов и мергелей. Отложения формировались в условиях субаэральной равнины, при редких высоких приливах и штормах, затапливающих супралитораль. В результате интенсивного испарения поровых вод и повышения концентрации солей в подповерхностных слабо литифицированных осадках происходило образование и разрастание сульфатных желваков [36].

Элювиальный горизонт. Породы фации представлены маломощными слоями карбонатных брекчий и конгломератов. Обломки от угловатых до окатанных, сцементированные глинисто-сульфатно-карбонатным материалом. Формирование происходило в периоды снижения относительного уровня моря и выхода карбонатных осадков в условия субаэральной экспозиции. Зачастую поверх них накладывалась себха $[37,38]$

Изолированный шельф (лагуна) - под данным определением авторы понимают полностью изолированный, лишенный привноса свежей морской воды из океана Панталасса участок мелководно-морского бассейна, от Прикаспийской впадины до побережья Печерского и Баренцева моря, в районе которого под действием аридного климата шло активное испарение, происходила садка сульфатов. 
Лагуна эвапоритовая. Фация представлена ангидритами от молочно-белых с голубоватым оттенком до голубовато-светло-серых, разнокристаллическими, от мелкокристаллических до крупно-желваковых с включениями и волнистыми прерывистыми прожилками серого и темно-серого глинисто-алевритового материала и доломита. Размеры желваков в пределах пачек имеют тенденцию к направленным изменениям: снизу вверх по мере сокращения содержания глинисто-терригенного и доломитового материала их размерность увеличивается. Формирование осадков происходило в условиях спокойной гидродинамики, затрудненном водообмене с открытым морским бассейном, при увеличенной солености и интенсивном испарении [39-41].

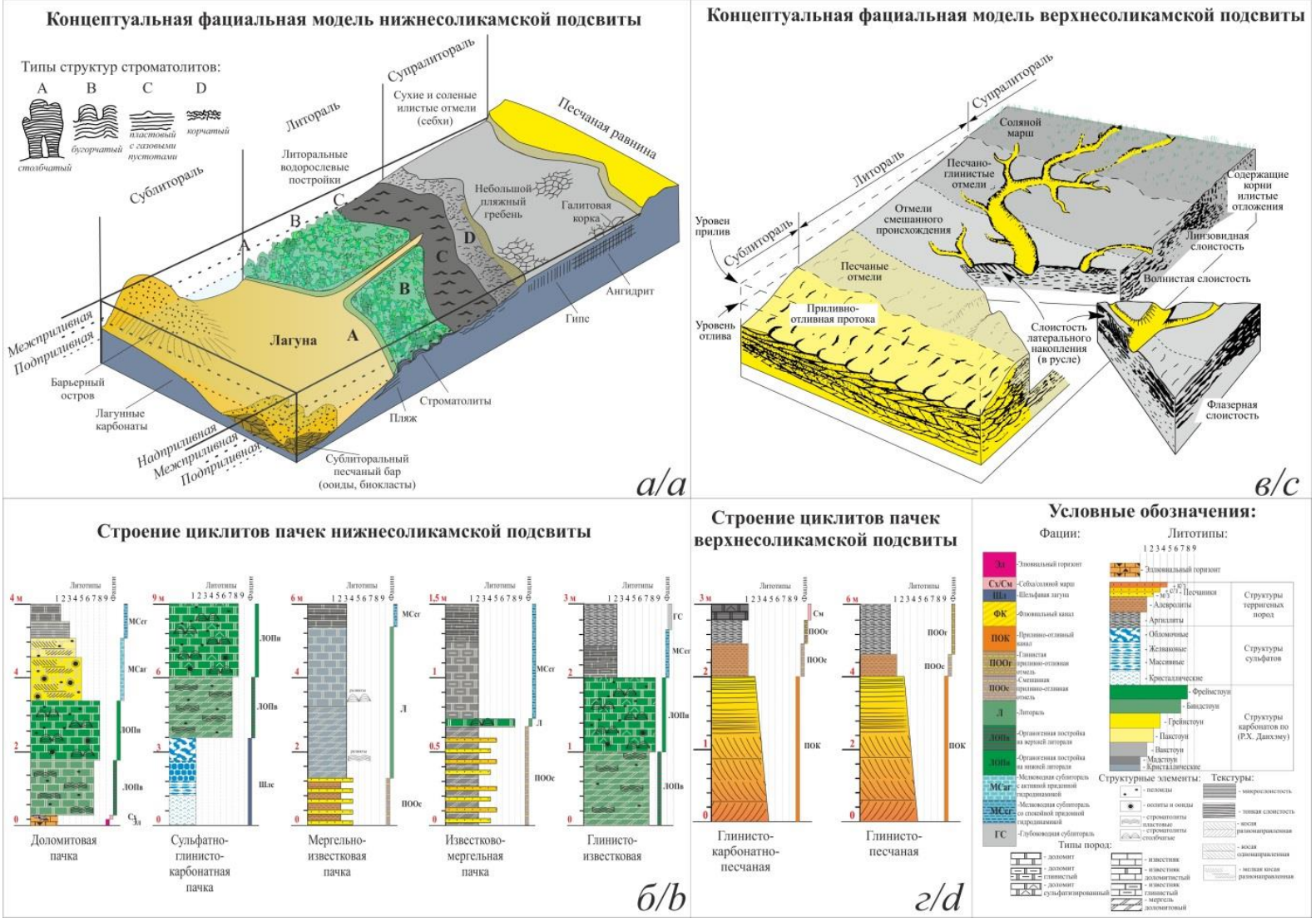

Рис. 7. Седиментологические модели с примером строения ичклов для нижнесоликамской (а, б) и верхнесоликамской $($ в, г) подсвиты: a) no Gerhard Einsele [20]; в) nо Roger Walker [29] с изменениями авторов

Fig. 7. Sedimentation models with an example of the structure of cycles for the Lower Solicamsk $(a, b)$ and Upper Solicam (c, d) subformation: a) by Gerhard Einsele [20]; c) by Roger Walker [29] modified by the authors

\section{Приливно-отливная отмель}

Приливно-отливный канал. Фация представлена песчаниками разнозернистыми, с карбонатным цементом, плохо сортированными, с разнонаправленной косой и неправильной слоистостью, и глинистоалевритовыми интракластами. Органические остатки представлены углефицированным растительным шламом. Накопление осадков происходило на мелководье при ритмично изменяющейся направленности и интенсивности гидродинамики приливно-отливных процессов [42].

Приливно-отливная отмель. Фация представлена тонкослоистыми алевритистыми песчаниками и песчанисто-глинистыми алевролитами с тонкими прослоями, и прожилками алевритистых аргиллитов. В зависимости от преобладающей гранулометрической фракции фация подразделяется на субфации: 1) песчаная приливно-отливная отмель (преобладают прослои песчаников); 2) смешанная приливно-отливная отмель (приблизительно равное соотношение песча- ной и алевритовой составляющей); 3) илистая приливно-отливная отмель (преобладание алевритового материала). В породах встречается углефицированный растительный шлам, фрагменты листьев и стеблей высших растений. Накопление осадков приливноотливных отмелей происходило на мелководье при ритмично изменяющемся воздействии приливноотливных процессов, перераспределяющих материал, привнесенный распределительными каналами дельты. Соленость воды периодически менялась [43].

Приливно-отливной мари представлен известняками глинистыми с прослоями и примесью песчаноглинистого материала, со структурой мадстоун, с частыми горизонтами элювия, с мелкими желваками и слоями ангидрита, с мелкими ризокрециями наземных растений. Осадки формировались в условиях очень слабой гидродинамики с ритмичными суточными проявлениями приливно-отливных процессов, изменчивой соленостью, частыми периодами субаэральной экспозиции [44]. 


\section{Фациальный анализ отложений шешминской свить}

В раннешешминское время, при трансгрессии моря, происходило формирование аллювиальнодельтового комплекса. Большая часть изучаемой территории представляла собой субаквальную часть дельтового побережья. В рамках данной статьи перечисления всего множества фаций данного комплекса не представляется возможным. Далее по тексту дается краткая характеристика условий осадконакопления

\section{Аллювиально-дельтовый комплекс}

Условия, в которых отлагались осадки, периодически менялись. При понижении базиса эрозии большая часть территории осушалась. Реки, стекающие со стороны Урала, выходили на равнину и создавали своими руслами глубокие врезы в ранее накопленных отложений. При начинающемся повышении базиса эрозии эрозионные ложбины заполнялись косослоистыми песчаниками, к которым, при высокой скорости течения, присоединялись линзы конгломерата При дальнейшем повышении базиса эрозии замедлялось течение рек, русловые врезы заполнялись песчаными осадками, полностью слагающими их к моменту наступления на сушу водного бассейна. Песчаный материал некоторое время продолжал поступать в прибрежно-морские зоны и незатопленного еще участка русла, образуя дельтовый вынос, зачастую выпуклую часть песчаной линзы. Реки образовывали старичные озера, которые испарялись, оставляя после себя сульфатизированные терригенные отложения. Дальнейшее повышение базиса эрозии в начале позднешешминского времени оттесняло дельтовую область на восток, и в рассматриваемом районе начиналось накопление дельтовых песчаных осадков (подводная часть дельты).

Bblводbl. Таким образом, отложения нижнесоликамской подсвиты формировались в условиях открытого шельфа и частично изолированного шельфа (лагуны), а породы верхнесоликамской подсвиты - в условиях приливно-отливной терригенной отмели. В это время господствовал аридный климат, литологические признаки которого представлены в предыдущем разделе. Представлены концептуальные седиментологические модели, показано строение циклитов. Важная смена условий осадконакопления фиксируется подошвой верхнесоликамской подсвиты, изученной в разрезе 54 км ГЖД. Побережье было вытянуто с севера на юг. Поступление терригенного материала происходило с палео-Урала с востока на запад в современном положении.

Сложность разреза красноцветной толщи шешминской свиты и многократное переслаивание литологически и фациально-различных пачек слоев указывает, что в шешминское время многократно изменялись физико-географические условия. То большая часть или даже вся область становилась низменной равниной с многочисленными текущими по ней реками, то в результате кратковременной трансгрессии моря ее заливали воды повышенной солености с формированием в старичных озерах сильно загипсованных глин и алевролитов. Большие объёмы поступаю- щей воды в условиях аридного климата могли сильно повысить влажность, что способствовало расселению растений. Возможно, повышенное содержание железа и меди также связано с процессами коагуляции этих элементов из раствора в результате смешения пресных и солёных вод, что характерно для субаквальной части дельты.

\section{Секвенс-стратиграфическое строение}

Разрез уфимского яруса разделен на два секвенса четвертого порядка (рис. 2).

Секвенс SQ1 (нижнесоликамская подсвита). В подошве секвенса выделяется стратиграфическое несогласие. Подошва окраинно-шельфового тракта (ОШТ) проведена по контакту сульфатов лунежской пачки иренской свиты кунгурского яруса и вышележащей доломитовой пачки нижнесоликамской подсвиты уфимского яруса, изученной авторами в цоколе третьего уступа Чумкасского карьера (рис. 8, a). На закарстованной эрозионной поверхности сульфатов залегает разнообломочная брекчия карбонатных пород со структурой мадстоун и строматолитовый баундстоун с оолитовым и микритовым заполнением, с желваками ангидрита и гипса (рис. 8, б-z). Размер обломков от первых сантиметров до 10 см (рис. $8, \partial, e)$. Таким образом, ОШТ имеет проградационное строение и представлен сульфатно-карбонатной брекчией супралиторали (рис. 2).

Трансгрессивная поверхность (ts) может быть проведена по кровле брекчии в подошве строматолитовых баундстоунов. По ней происходит смена пакета парасеквенса на ретроградационный. Ретроградационное строение ТСТ подтверждается углубляющейся вверх по разрезу последовательностью фаций, изученных в пачках нижнесоликамской подсвиты, снизу вверх: $\quad$ супралитораль $\rightarrow$ литораль $\rightarrow$ сублитораль $\rightarrow$ глубокая сублитораль $\rightarrow$ мелководная сублитораль $\rightarrow$ литораль $\rightarrow$ супралитораль/приливно-отливная глинисто-терригенная отмель (рис. 7, б).

Поверхность максимального затопления (msf) может быть проведена в подошве глинистоизвестковистой пачки нижнесоликамской подсвиты по смене ретроградационного пакта парасеквенса на агградационный. ТВС имеет агградационное строение и представлен карбонатно-глинистыми отложениями сублиторали.

Секвенс SQ2 объединяет верхнесоликамскую подсвиту и шешминскую свиту. Подошва секвенса фиксирует стратиграфическое несогласие. Подошва ТНС и ТСТ проведена по контакту глинисто-известковой пачки и вышележащей аргиллито-известковопесчаной пачки в разрезе «54 км ГЖД» (рис. 9, a). Для очистки границы была применена тяжелая техника (рис. 9, б). Ниже границы секвенса наблюдаются карбонаты литорали, перекрытые глинистыми терригенно-карбонатными породами сублиторали. На них эрозионно залегают массивные крупносреднезернистые песчаники приливно-отливных каналов с косой разнонаправленной слоистостью (рис. 9, в). Неразделенные ТНС и ТСТ представлены глинисто-песчаными осадками приливно-отливной 
отмели и имеют в общем ретроградационное строение (пачки верхнесоликамской подсвиты) (рис. 7, 2).
Отложения трактов залегают в верхней части склона разреза «54 км ГЖД» (рис. 9, г).
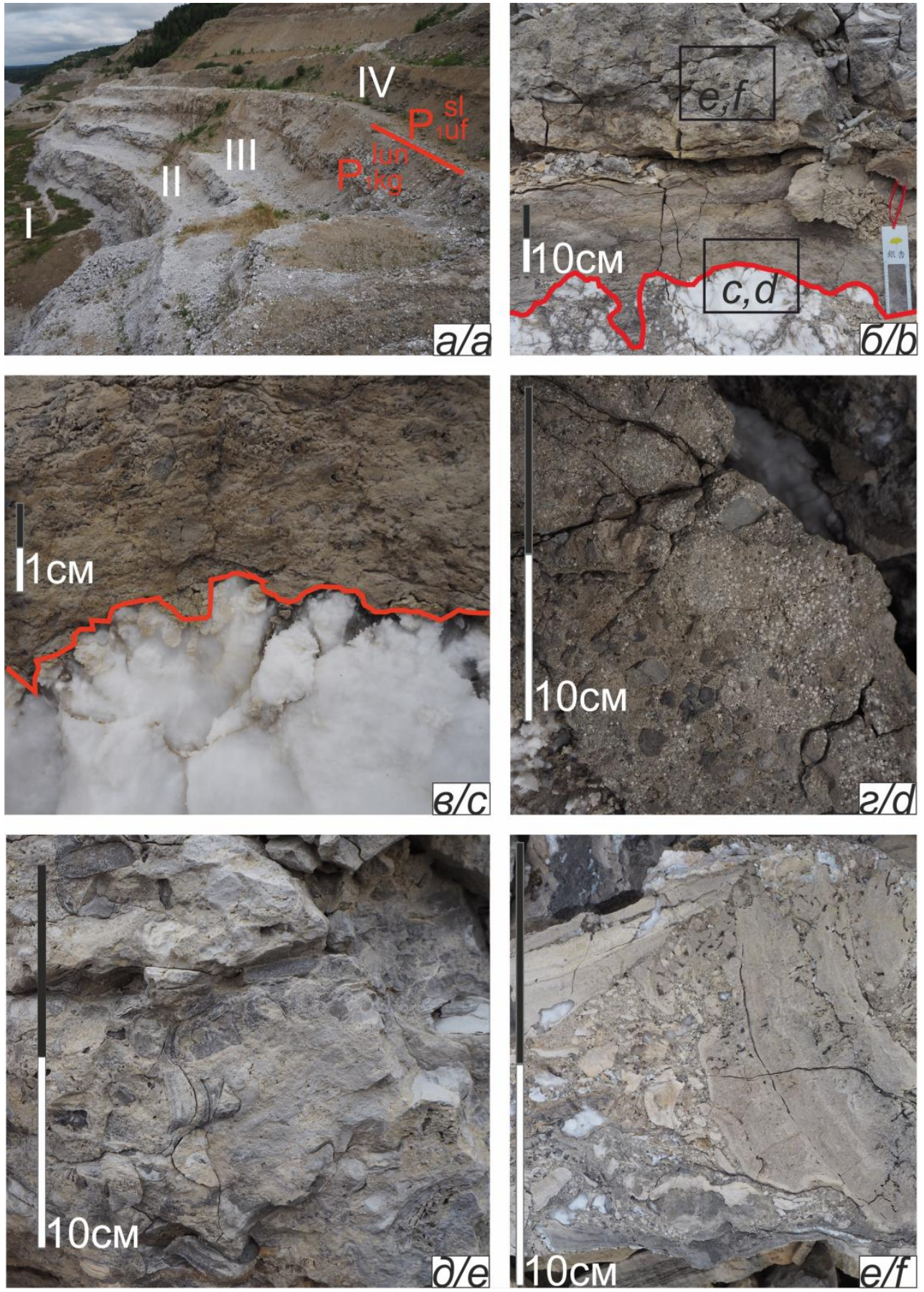

Pис. 8. Фототаблица границы кунгурского и уфимского яруса в разрезе Чумкасский карьер: а) местоположение границы в иоколе III уступа; б) контакт ангидритов лунежской пачки иренской свиты кунгурского яруса и вышележащих карбонатов соликамской свиты уфимского яруса. Квадратами выделены участки, которые рассматриваются далее; в) контакт ангидритов лунежсккой пачки и карбонатной брекчии; г) разнообломочная карбонатная брекчия с ооидным и микритовым заполнением; д) карбонатная брекчия, состоящая из обломков строматолитовых баундстоунов; е) карбонатная брекчия разнообломочная, с обломками с реликтовой структурой баундстоун и мадстоун, с сульфатным иементом

Fig. 8. Photo table of the boundary between the Kungur and Ufa stages in the section of the Chumkassky quarry: a) location of the border in the base of the III ledge; b) contact of anhydrites of the Lunezhskaya Member of the Irenskaya Formation of the Kungurian stage and the overlying carbonates of the Solikamskaya Formation of the Ufa stage. Sections are marked with squares, which are considered below; c) contact of anhydrites of the Lunezhskaya member and carbonate breccia; d) mixed-clastic carbonate breccia with ooid and micritic filling; e) carbonate breccia consisting of stromatolite boundstones; $f$ ) carbonate breccia of different detrital type with fragments with relict boundstone and madstone structure, with sulfate cement 

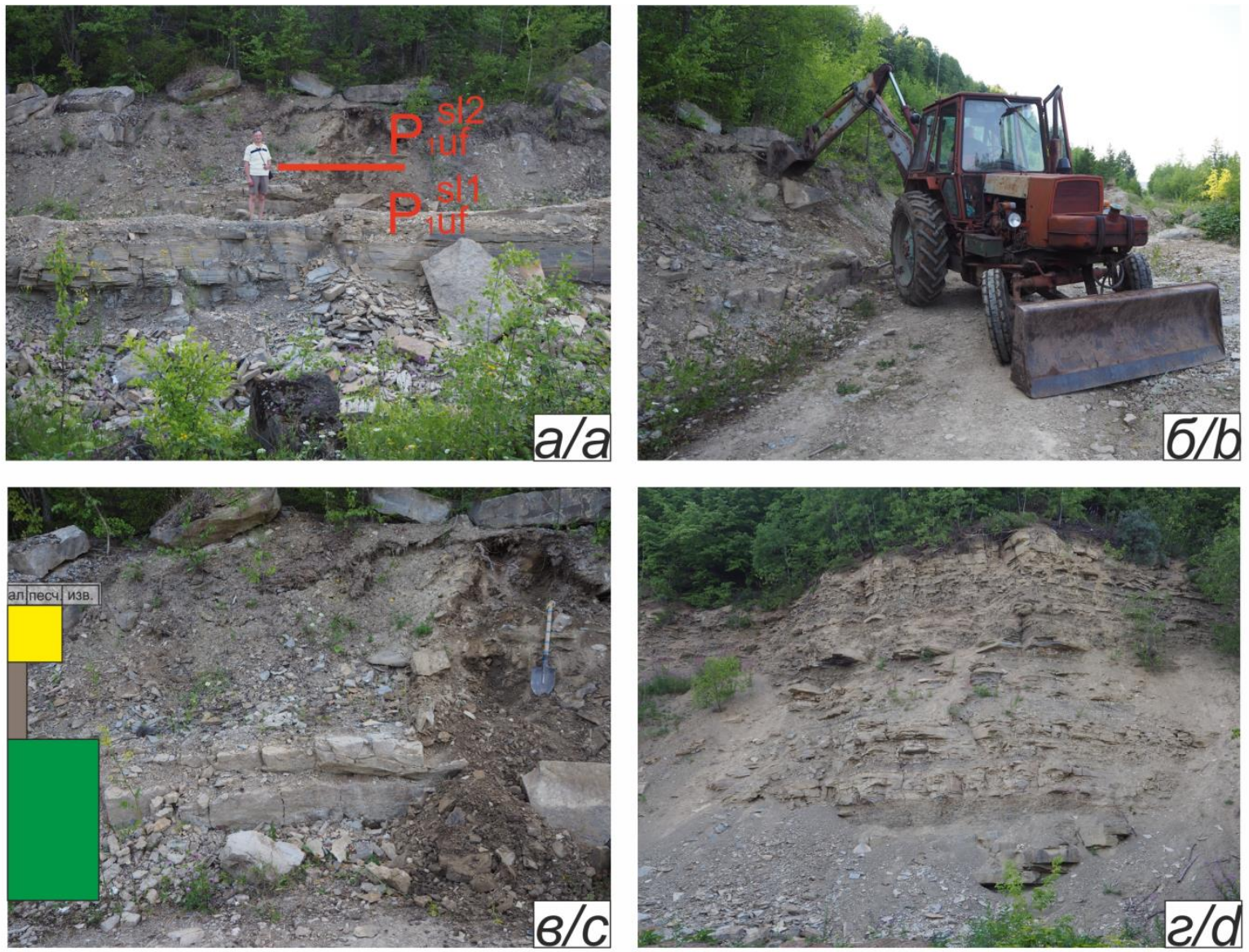

Рис. 9. Фототаблица границь нижне- и верхнесоликамской подсвиты уфимского яруса в разрезе «54 км ГЖД»: а) положение границы в разрезе; б) расчистка границы тяжелой техникой; в) фото границы с схематической зарисовкой литологии; г) вышележащие карбонатно-терригенные отложения верхнесоликамской подсвить

Fig. 9. Photo table of the boundary of the Lower and Verkhnesolikamsk subformation of the Ufa stage in the section «54 km railroad station»: a) position of the border in the section; b) clearing the border with heavy equipment; c) photo of the boundary with a schematic sketch of lithology; d) overlying carbonate-terrigenous deposits of the Verkhnesolikamsk subformation

Поверхность максимального затопления (msf) может быть проведена в подошве песчано-глинистой пачки нижнешешминской подсвиты по смене ретроградационного пакта парасеквенса на агградационнопроградационный. Отложения ТВС представлены аллювиально-дельтовым комплексом, проградирующим в западном направлении.

Граница Sb2 проведена по кровле мелководноморских мергелей, которые эрозионно перекрываются песчаниками казанского возраста. Тем самым на границе фиксируется и стратиграфическое несогласие (рис. 2).

Bblвodы. Таким образом, первый секвенс, соответствующий объёму нижнесоликамской подсвиты, показывает переход от супралиторальных к сублиторальным фациям, свидетельствует о трансгрессии эпиконтинентального морского бассейна. Второй секвенс, выделенный в объёме верхнесоликамской подсвиты и шешминской свиты, демонстрирует начало регрессии моря, способствовавшей активной проградации приливно-отливного глинисто-терригенного комплекса в бассейн. Данный этап является началом формирования красноцветного терригенного комплекса пермской системы.

\section{Заключение}

В результате исследований авторами приведено детальное описание вещественного состава, особенностей строения разреза соликамской и шешминской свит. Освещенное строение пачек терригеннокарбонатного типа разреза соликамской свиты и терригенный тип разреза шешминской свиты показывают особенности осадконакопления центральной части Пермского края района города Перми.

Изученный терригенно-карбонатный тип разреза соликамской свиты отражает важный этап перехода от пермских эвапоритов к красноцветной терригенной формации. Разрез разделен на два секвенса четвертого порядка.

Таким образом, описан важный этап развития пермского периода: окончательный переход от мелководно-морского к континентальному осадконакоплению. Известно, что в нижней части уфимского яруса, в нижнесоликамской подсвите, ещё встречаются руководящие формы фауны кунгурского возраста, однако проведенные литологические исследования показали переходный характер сульфатнокарбонатно-мергельных отложений данного комплекca, не позволяющий синхронизировать его с разрезом 
валидного кунгурского яруса, как и вышезалегающие терригенно-карбонатные и терригенные пачки уфимского яруса.

По мнению авторов, уфимский ярус должен относиться к среднему отделу пермской системы.

Авторы выражают благодарность за консультации и координацию полевых работ преподавателям Пермского государственного наиионального исследовательского университета: Раисе Андреевне Лядовой и Анатолию Сергеевичу Сунцеву. Ценные смысловые и редакиионные замечания доктора геолого-минералогических наук, профессора РАН Сергея Владимировича Наугольных помогли улучшить содержание статьи.

\section{Памяти нашего учителя посвящается}

В начале 2000-х г2. в одной из школ на окраине Перми начал работать геологический кружок при кабинете

\section{СПИСОК ЛИТЕРАТУРЬ}

1. Чувашов Б.И. Кунгурский ярус пермской системы (проблемь выделения и корреляции) // Стратиграфия. Геологическая корреляция. - 1997. - Т. 5. - № 3. - С. 10-28.

2. Голубев В.К. Стратиграфическая и геоисторическая шкалы: к вопросу о модернизации общей стратиграфической шкаль пермской системы // Структура и статус ВосточноЕвропейской стратиграфической шкалы пермской системы, усовершенствование ярусного расчленения верхнего отдела пермской системы общей стратиграфической шкалы: Доклады всероссийского совещания. - Казань: КГУ, 2004. - С. 3-6.

3. Котляр Г.В., Голубев В.К., Силантьев В.В. Общая стратиграфическая шкала пермской системы: современное состояние // Общая стратиграфическая шкала России: состояние и перспективы обустройства. - М.: ГИН РАН, 2013. - С. 171-179.

4. Наугольных С.В. Новые мужские репродуктивные органы голосеменных Permotheca colovratica sp. nov. из пермских отложений Урала // Палеонтологический журнал. - 2013. - № 1. C. 91-102.

5. Наугольных С.В. Юговская флора Среднего Приуралья // Палеоэкология. Методологические основы, фактологический потенциал, применение в музейных экспозициях. - М.: Изд-во «Медиа-Гранд», 2017. - С. 45-74.

6. Тимофеев В.Д. Горнозаводское кольцо Прикамья. Путеводитель-справочник по горно-геологическим памятникам пермского края. - Екатеринбург: Изд-во «Издательские решения», 2017. - 305 c.

7. Геологические памятники Пермского края. Энциклопедия под ред. И.И. Чайковского. - Пермь: Изд-во «Книжная площадь», 2009. - $616 \mathrm{c.}$

8. Стратиграфический словарь СССР (карбон, пермь). - Л.: Недра, 1977. - 535 с.

9. Структурная геология и геологическое картирование. Геологическое строение района г. Перми / А.С. Сунцев, 3.А. Леонова-Вендровская, М.И. Денисов, И.И. Черткова. - Пермь: ПГУ 2000. - 104 c.

10. Лозовский В.Р., Миних М.Г., Грунт Т.А. Уфимский ярус восточно-европейской шкалы: статус, валидность, корреляционный потенциал // Стратиграфия. Геологическая корреляция. 2009. - Т. 17. - № 6. - С. 46-58.

11. Стратиграфический кодекс России. Издание третье, исправленное и дополненное. - СПб.: ВСЕГЕИ, 2019. - 96 с.

12. Копнин В.И. Геологические экскурсии по окрестностям городов Перми и Кунгура. - Пермь: ПГТУ, 1993. - 54 с.

13. Сунцев А.С. Соликамский горизонт в окрестностях Перми // Пермская система: стратиграфия, палеонтология, палеогеография, геодинамика и минеральные ресурсы: материалы конференции, посвящённой 170-летию со дня открытия пермской системы. - Пермь, 2011. - С. 205-208

14. Силантьев В.В. Палеомутелы (неморские двустворки) соликамского горизонта Соликамской впадины // Бюллетень Московского общества испытателей природы. Отдел геологии. 1995. - T. 70, - № 5 - C. 73-82. географии. Занятия с детьми вела Работа Людмила Алексеевна, географ по образованию, геолог по призванию и учитель от бога. Человек очень увлеченный естественными науками. В рамках геологического клуба ребята начали активно ездить по окрестностям города, знакомясь с породами пермской системь, в частности уфимского яруса. Школьными геологическими марирутами обошли авторы отложения соликамской и шешминской свитьл. Именно в то время авторами были сделаны многие уникальные открытия местонахождений уфимской флоры и медной минерализации. Благодаря своему учителю именно с медистых песчаников началась любовь $\kappa$ геологии. За более чем 15 лет Людмила Алексеевна для своих ребят стала второй мамой, наставником и советником по многим вопросам. Через нее прошло несколько сотен ребят, которые хоть и не все пошли по геологическому пути в дальнейшем, но любовь $к$ природе, к Земле останется в их сердиах навсегда.

15. Силантьев В.В. Соликамский горизонт Пермского Приуралья // Стратотипы и опорные разрезы Поволжья и Прикамья. - Казань: Изд-во «Экоцентр», 1996. - С. 13-55.

16. Наугольных С.В. Юговская флора (уфимский ярус, верхняя пермь) Приуралья // Проблемы региональной геологии: музейный ракурс. - М.: Изд-во «Акрополь», 2004. - С. 168-172.

17. Наугольных С.В. Пермские флоры Урала // Труды ГИН РАН Выпуск 580. - М.: ГЕОС, 2007. - 400 с.

18. Наугольных С.В. Литвинова Т.В. Строматолиты из пермских отложений Пермского Приуралья: новый форм-род Alebastrophyton Naug. et Litvinova, gen. Nov // Палеонтология в музейной практике. - М.: Изд-во «Медиа-Гранд», 2014. C. $33-43$.

19. Калинина Т.А. Литология нижнепермских карбонатных и сульфатных эвапоритов района «классического» Кунгура Пермский край) // Вестник Пермского университета. Геология. - 2015. - № 3 (28). - С. 6-27.

20. Einsele G. Sedimentary basins: Evolution, facies and sediment budget. - Heidelberg: Springer-Verlag, 2000. - 792 p.

21. Posamentier H.W., Allen G.P. Siliciclastic sequence stratigraphy: concepts and applications // SEPM, Concepts in Sedimentology and Paleontology 1999. - V. 7. - 210 p.

22. Schreiber B.S., El Tabakh M. Deposition and early alteration of evaporates // Sedimentary. - 2000. - V. 47. - P. 215-238.

23. Warren J.K. Evaporites: sediments, resources and hydrocarbons. Berlin: Springer-Verlag, 2006. - $1035 \mathrm{p}$

24. Маслов А.В. Осадочные породы: методы изучения и интерпретация полученных данных. - Екатеринбург: УГГУ, 2005. 289 c.

25. Dunham R.J. Classification of carbonate rocks according to deposition texture // Classification of Carbonate rocks. - Tulsa: Simposium Amer. Assoc. Petrol.Geol. Mem, 1962. - P. 108-121.

26. Radley J.D., Barker M.J., Munt M.C. Bivalve trace fossils (Lockeia) from the Barnes High Sandstone (Wealden Group, Lower Cretaceous) of the Wessex Sub-basin, southern England // Cretaceous Research. - 1998. - V. 19. - P. 505-509.

27. Плюснин А.В. Левшинская пачка шешминского горизонта юго-восточной окраины г. Перми // Пермская система: стратиграфия, палеонтология, палеогеография, геодинамика и минеральные ресурсы. - Пермь: Изд-во Пермского университета, 2011. - C. 164-167.

28. Плюснин А.В. Таксономический состав ископаемой флоры из местонахождения 30 км и Протон (шешминской горизонт, уфимский ярус; Пермский край) // Палеонтология и эволюция биоразнообразия в истории Земли. - М.: Изд-во ГЕОС, 2012. C. $63-70$.

29. Control of sea level change / A.G. Plint, N. Eyles, C.H. Eyles, R.G. Walker // Facies models: response to sea level change. Canada: Geological Association of Canada, 1992. - P. 15-25.

30. Kavinate S., Udchachon M., Fontaine H.L. Stratigraphy and Palaeontology of mid-Carboniferous Sequences at Phu Bo Bit in Loei Province, Thailand // Annales De Paleontologie. - 2019. V. 105. - P. 191-199. 
31. Depositional model for a salinized lacustrine basin: the Permian Lucaogou Formation, Jimsar Sag, Junggar Basin, NW China / Y. Yang, L. Qiu, M.W. Wan, X. Jia, Y. Cao, D. Lei, C. Qu // Journal of Asian Earth Sciences. - 2019. - V. 178. - P. 81-95.

32. Sedimentary dynamics of a subtropical tidal flat sheltered inside a coastal channel (Araçá Bay, SE Brazil) / J. Alcántara-Carrió, M.M. Mahiques, S.C. Goya, A. Fontán-Bouzas // Ocean \& Coastal Management. - 2017. - V. 164. - P. 32-41.

33. The biogeomorphology of Shark Bay's microbialite coasts T.E. Morris, P.T. Visscher, M. O'Leary, P. Fearns, B. Collins // Earth-Science Reviews. - 2020. - V. 205. - P. 102921-103173

34. Microbialite fields developed in a protected rocky coastline: The shallow carbonate ramp of the Aptian Romualdo Formation (Araripe Basin, NE Brazil) / F.G. Varejão, F.T. Fuersich, L.V. Warren, S.A. Matos, M.G. Rodrigues, M.L. Assine, A. Sales, M.G. Simões // Sedimentary Geology. - 2019. - V. 389. - P. 103-120.

35. Stratigraphic relationships between shallow-water carbonates and primary gypsum: insights from the Messinian succession of the Sorbas Basin (Betic Cordillera, Southern Spain) / M. Roveri, S. Lugli, V. Manzi, M. Reghizzi, F.P. Rossi // Sedimentary Geology. - 2020. - V. 404. - P. 1617-1637.

36. Middle Triassic evaporite sedimentation in the Catalan basin implications for the paleogeographic evolution in the NE Iberian platform / F. Ortí, J.M. Salvany, L.F. Rosell, X.P. Castelltort, M. Inglés, E. Playà // Sedimentary Geology. - 2018. - V. 374. P. $158-178$

37. Wright V.P. Paleosols in shallow marine carbonate sequences // Earth-Science Reviews. - 1994. - V. 35. - P. 367-395.

38. Fu Q. Characterization and discrimination of paleokarst breccias and pseudobreccias in carbonate rocks: Insight from Ordovician strata in the northern Tarim Basin, China // Sedimentary Geology. 2019. - V. 382. - P. 61-74.

39. Soto J.I., Flinch J.F., Tari G.C. Permo-Triassic basins and tectonics in Europe, North Africa and the Atlantic Margin // Tectonics and Hydrocarbon Potential. - 2017. - V. 1. - P. 3-41

40. Strohmenger C., Voigt E.B., Zimdars J. Sequence stratigraphy and cyclic development of Basal Zechstein carbonate-evaporite deposits with emphasis on Zechstein 2 off-platform carbonates (Upper Permian, Northeast Germany) // Sedimentary Geology. 1996. - V. 102. - P. 33-54.

41. Warren J.K. Evaporites through time: tectonic, climatic and eustatic controls in marine and nonmarine deposits // EarthScience Reviews. - 2010. - V. 98. - P. 217-268.

42. Lageweg W.I., Feldman H. Process-based modelling of morphodynamics and bar architecture in confined basins with fluvial and tidal currents // Marine Geology. - 2018. - V. 398. P. 35-47.

43. Facies associations, detrital clay grain coats and mineralogical characterization of the Gironde estuary tidal bars. A modern analogue for deeply buried estuarine sandstone reservoirs / M. Virolle, H. Féniès, B. Brigaud, R. Bourillot, E.J. Portier, P. Patrier, D. Beaufort, I. JalónRojas, H. Derriennic, S. Miska // Marine and Petroleum Geology. 2020. - V. 114. - P. 104225-104232.

44. Dai-du F., Yuan W., Min L. Classifications, sedimentary features and facies associations of tidal flats // Journal of Palaeogeography. -2013 . -V. 2. - P. 66-80.

Поступила 09.12.2020 г.

\section{Информация об авторах}

Плюснин Алексей Владимирович, студент, Пермский государственный национальный исследовательский университет.

Сулима Александр Иванович, аспирант, Пермский государственный национальный исследовательский университет.

Тимофеев Владислав Дмитревич, студент, Пермский государственный национальный исследовательский университет.

Коваль Дмитрий Валерьевич, студент, Пермский государственный национальный исследовательский университет.

Дементьева Ксения Владимировна, студентка магистратуры, Пермский государственный национальный исследовательский университет. 
UDC 551.31: $551.736 .1(470.53)$

\section{LITHOLOGICAL-FACIAL STRUCTURE OF THE UFA SEDIMENTS IN THE CENTRAL PART OF THE PERM KRAI}

Alexey V. Plyusnin'1,
A.V.Plyusnin@mail.ru

Alexander I. Sulima ${ }^{1}$, super.sulima2013@yandex.ru

Vladislav D. Timofeev ${ }^{1}$, immrill@yandex.ru

\section{Dmitry V. Koval ${ }^{1}$,} koval0806@yandex.ru

Ksenia V. Dementyeva ${ }^{1}$, demksevla@yandex.ru

1 Perm State National Research University,

15, Bukirev street, Perm, 614068, Russia.

The relevance of the study is caused by the need to clarify the lithological-facies and sequence-stratigraphic structure of the sediments of the Uralian section of the Permian system. Today, there is a problem of the stratigraphic position and independence of the Ufa stage. Over the past three decades, researchers have expressed various assumptions about changes in the volumes of the longline. Due to the peculiarities of sedimentation, the main biostratigraphic groups for the Volga-Kama region are: ostracods, pelecypods, spores and pollen, plant remains, fragments of fish and vertebrates, the distribution intervals of which are limited by the boundaries of facies zones. Hence, there is a limitation of biostratigraphic methods, due to which researchers have not been able to clearly define the boundaries and volume of the stage until now.

Purpose: division of sediments into fourth order sequences and clarification of the lithological-facies structure.

Objects: geological sections and oil wells in the central part of the Perm region.

Methods: geo-mapping of geological sections; borehole correlation; lithological-facies description; paleogeographic reconstructions.

Results. Correlation of the most typical sections helped the authors describe the structure, material composition and build a composite section of the Ufa stage. The submeridional profile for the studied wells made it possible to show a change in the types of the section over the area from the maximum thickness in the area of the Solikamsk and Visim depression to the normal platform part of the Perm territory. In the section of the Ufa stage, two fourth-order sequences have been identified. The first sequence corresponds in volume to the Lower Solicam sub-formation. The second sequence is identified in the volume of the Verkhnesolikamsk subformation and Sheshminskaya formation. Stratigraphic unconformities with signs of subaerial exposure were recorded at the border of the Kungurian and Ufa stages and the lower and upper Solikamsk subformation.

\section{Key words:}

Stratigraphy, Permian system, Ufa stage, sequence stratigraphy, lithofacies variability.

The authors thank Raisa Andreevna Lyadova and Anatoly Sergeevich Suntsev, the teachers of the Perm State National Research University, for consultation and coordination of field work. Valuable semantic and editorial remarks of Doctor of Geological and Mineralogical Sciences, Professor of the Russian Academy of Sciences Sergei Vladimirovich Naugolnykh helped to improve the content of the article.

\section{REFERENCES}

1. Chuvashov B.I. Kungurian stage of the Permian system (problems of isolation and correlation). Stratigraphy. Geological correlation, 1997, vol. 5, no. 3, pp. 212-230. In Rus.

2. Golubev V.K. Stratigraficheskaya i geoistoricheskaya shkaly: k voprosu o modernizatscii obshchey stratigraficheskoy shkaly permskoy sistemy [Stratigraphic and geohistorical scales: on the issue of modernization of the General stratigraphic scale of the Permian system]. Doklady vserossiyskogo soveshchaniya. Struktura $i$ status Vostochno-Evropeyskoy stratigraficheskoy shkaly permskoy sistemy, usovershenstvovanie yarusnogo raschleneniya verkhnego otdela permskoy sistemy obshchey stratigraficheskoy shkaly [Reports of the All-Russian meeting. The structure and status of the East European stratigraphic scale of the Permian system, improvement of the tiered dissection of the upper section of the Permian system of the general stratigraphic scale]. Kazan, Kazan State University Publ., 2004. pp. 3-6.
3. Kotlyar G.V., Golubev V.K., Silantiev V.V. Obshchaya stratigraficheskaya shkala permskoy sistemy: sovremennoe sostoyanie [General stratigraphic scale of the Permian system: current state of affairs]. Obshchaya stratigraficheskaya shkala Rossii: sostoyanie i perspektivy obustrojstva [General stratigraphic scale of Russia: state and prospects of development]. Moscow, GIN RAS Publ., 2013. pp. 171-179.

4. Naugolnykh S.V. New male reproductive organs of gymnosperms Permotheca colovratica sp. nov. from Permian deposits of the Urals. Paleontologichesky zhurnal, 2013, vol. 1, pp. 91-102. In Rus.

5. Naugolnykh S.V. Yugovskaya flora Srednego Priuralya [Yugovian flora of the Middle Cis-Urals]. Paleoekologiya. Metodologicheskie osnovy, faktologicheskiy potentscial, primenenie v muzejnykh ekspoziciyakh [Palaeoecology. Methodological basis, factological potential, application for museum expositions]. Moscow, MediaGrand Publ., 2017. pp. 45-74. 
6. Timofeev V.D. Gornozavodskoe koltso Prikamya. Putevoditelspravochnik po gorno-geologicheskim pamyatnikam permskogo kraya [Mining the ring of the Kama region. Guide to the mining and geological monuments of the Perm region]. Ekaterinburg, Izdatelskie resheniya Publ., 2017. 305 p.

7. Geologicheskie pamyatniki Permskogo kraya. Entsiklopediya [Geological monuments of the Perm region. Encyclopedia]. Perm, Knizhnaya ploshchad Publ., 2009. 616 p.

8. Stratigrafichesky slovar SSSR (karbon, perm) [Stratigraphic dictionary of the USSR (carbon, perm)]. Leningrad, Nedra Publ., 1977. $535 \mathrm{p}$.

9. Suntsev A.S., Leonova-Vendrovskaya Z.A., Denisov M.I., Chertkova I.I. Geologicheskoe stroenie rayona g. Permi [Geological structure of the Perm region]. Perm, PGU Publ., 2000. 104 p.

10. Lozovskii V.R., Minikh M.G., Grunt T.A. The Ufimian Stage of the East European Scale: Status, Validity, Correlation Potential. Stratigraphy. Geological correlation, 2009, vol. 17, no. 6, pp. 46-58. In Rus.

11. Stratigrafichesky kodeks Rossii [Stratigraphic code of Russia]. St. Petersburg, VSEGEI Publ., 2019. 96 p.

12. Kopnin V.I. Geologicheskie ekskursii po okrestnostyam gorodov Permi i Kungura [Geological excursions in the surroundings of Perm and Kungur]. Perm, PITU Publ., 1993. 54 p.

13. Suntsev A.S. Solikamskiy gorizont v okrestnostyakh Permi [Solikamskian horizon in the vicinity of Perm]. Permskaya sistema: stratigrafiya, paleontologiya, paleogeografiya, geodinamika mineralnye resursy. Materialy konferentsii, posvyashchennoy 170-letiyu so dnya otkrytiya permskoy sistemy [Permian system: stratigraphy, paleontology, paleogeography, geodynamics and mineral resources. Proc. of the conference dedicated to the $170^{\text {th }}$ anniversary of the discovery of the Permian system]. Perm, 2011. pp. 205-208.

14. Silantyev V.V. Palaeomutela (not sea bivalves) of the Solikamsk Horizon of the Solikamsk depression. Byulleten Moskovskogo obshchestva ispytateley prirody. Otd. geol, 1995, vol. 70 (5), pp. 73-82. In Rus.

15. Silantyev V.V. Solikamskiy gorizont Permskogo Priuralya [Solikamsk horizon of the Permian Ural]. Stratotipy i opornye razrezy Povolzhya i Prikamya [Stratotipes and main sections of Volga and Kama regions]. Kazan, Eco-Center Publ., 1996. pp. 13-55.

16. Naugolnykh S.V. Yugovskaya flora (ufimskiy yarus, verkhnyaya perm Priuralya [Yugovskaya flora (Ufa tier, upper Perm) of the Urals]. Problemy regionalnoy geologii: muzeyny rakurs [Problems of regional geology: museum perspective]. Moscow, Akropol Publ., 2004. pp. 168-172.

17. Naugolnykh S.V. Permskie flory Urala [Permian flora of the Urals]. Moscow, GIN RAN Publ., 2007. Vol. 580. 400 p.

18. Naugolnykh S.V., Litvinova T.V. Stromatolity iz permskikh otlozheniy Permskogo Priuralya: novy form-rod Alebastrophyton Naug. et Litvinova, Gen. nov. [Stromatolites from the Permian deposits of the Perm Cis-Urals: a new form-genus Alebastrophyton Naug. et Litvinova, Gen. nov.]. Paleontologiya v muzeynoy prak tike [Palaeontology in the museum practice]. Moscow, MediaGrand Publ., 2014. pp. 33-43.

19. Kalinina T.A. Lithology of Lower Permian Carbonate and Sulfate Evaporites at the Area of a «Classical» Kungurian sediments: Perm kray. Vestnik Permskogo universiteta. Geologiya, 2015, vol. 3 (28), pp. 6-27. In Rus.

20. Einsele G. Sedimentary basins: evolution, facies and sediment budget. Heidelberg, Springer-Verlag Publ., 2000. 792 p.

21. Posamentier H.W., Allen G.P. Siliciclastic sequence stratigraphy: concepts and applications. SEPM Concepts in Sedimentology and Paleontology, 1999, vol. 7, $210 \mathrm{p}$.

22. Schreiber B.S., El Tabakh M., Deposition and early alteration of evaporates. Sedimentary, 2000, vol. 47, pp. 215-238.

23. Warren J.K. Evaporites: sediments, resources and hydrocarbons. Berlin, Springer-Verlag, 2006. $1035 \mathrm{p}$

24. Maslov A.V. Osadochnye porody: metody izucheniya $i$ inter pretatsiya poluchennykh dannykh [Sedimentary rocks: methods for studying and interpreting the data obtained]. Ekaterinburg, UGGU Publ., 2005. 289 p.

25. Dunham R.J. Classification of carbonate rocks according to deposition texture. Classification of Carbonate rocks. Tulsa, Simposium Amer. Assoc. Petrol.Geol. Mem, 1962. pp. 108-121.
26. Radley J.D., Barker M.J., Munt M.C. Bivalve trace fossils (Lockeia) from the Barnes High Sandstone (Wealden Group, Lower Cretaceous) of the Wessex Sub-basin, southern England. Cretaceous Research, 1998. vol. 19, pp. 505-509.

27. Plyusnin A.B. Levshinskaya pachka sheshminskogo gorizonta yugo-vostochnoy okrainy g. Permi [Levshinskiy pack of sheshmian horizon of South-Eastern outskirts of the city of Perm]. Permskaya sistema: stratigrafiya, paleontologiva, paleogeografiya, geodinamika $i$ mineral'ye resursy [Permian system: stratigraphy, paleontology, paleogeography, geodynamics and mineral resources]. Perm, Perm University Publ., 2011. pp. 164-167.

28. Plyusnin A.V. Taksonomicheskiy sostav iskopaemoy flory iz mestonakhozhdeniya $30 \mathrm{~km}$ i Proton (sheshminsky gorizont, ufimskiy yarus; Permskiy kray) [Taxonomic composition of fossil flora from the $30 \mathrm{~km}$ and Proton localities (sheshmian horizon, Ufa tier; Perm region)]. Paleontologiya i evolyutsiya bioraznoobraziya $v$ istorii Zemli. Sbornik nauchnykh rabot [Paleontology and evolution of biodiversity in the history of the Earth]. Moscow, GEOS Publ., 2012. pp. 63-70.

29. Plint A.G., Eyles N., Eyles C.H., Walker R.G. Control of sea level change. Facies models: response to sea level change. Canada, Geological Association of Canada, 1992. pp. 15-25.

30. Kavinate S., Udchachon M., Fontaine H.L. Stratigraphy and Palaeontology of mid-Carboniferous Sequences at Phu Bo Bit in Loei Province, Thailand. Annales De Paleontologie, 2019, vol. 105, pp. 191-199.

31. Yang Y., Qiu L., Wan M.W., Jia X., Cao Y., Lei D., Qu C. Depositional model for a salinized lacustrine basin: the Permian Lucaogou Formation, Jimsar Sag, Junggar Basin, NW China. Journal of Asian Earth Sciences, 2019, vol. 178, pp. 81-95.

32. Alcántara-Carrió J., Mahiques M.M., Goya S.C., Fontán-Bouzas Á. Sedimentary dynamics of a subtropical tidal flat sheltered inside a coastal channel (Araçá Bay, SE Brazil). Ocean \& Coastal Management, 2017, vol. 164, pp. 32-41.

33. Morris T.E., Visscher P.T., O'Leary M., Fearns P., Collins B. The biogeomorphology of Shark Bay's microbialite coasts. EarthScience Reviews, 2020, vol. 205. pp. 102921-103173

34. Varejão F.G., Fuersich F.T., Warren L.V., Matos S.A., Rodrigues M.G., Assine M.L., Sales A., Simões M.G. Microbialite fields developed in a protected rocky coastline: The shallow carbonate ramp of the Aptian Romualdo Formation (Araripe Basin, NE Brazil). Sedimentary Geology, 2019, vol. 389, pp. 103-120.

35. Roveri M., Lugli S., Manzi V., Reghizzi M., Rossi F.P. Stratigraphic relationships between shallow-water carbonates and primary gypsum: insights from the Messinian succession of the Sorbas Basin (Betic Cordillera, Southern Spain). Sedimentary Geology, 2020, vol. 404, pp. 1617-1637.

36. Ortí F., Salvany J.M., Rosell L.F., Castelltort X.P., Inglés M., Playà E. Middle Triassic evaporite sedimentation in the Catalan basin: Implications for the paleogeographic evolution in the NE Iberian platform. Sedimentary Geology, 2018, vol. 374, pp. 158-178.

37. Wright V.P. Paleosols in shallow marine carbonate sequences. Earth-Science Reviews, 1994, vol. 35, pp. 367-395.

38. Fu Q. Characterization and discrimination of paleokarst breccias and pseudobreccias in carbonate rocks: Insight from Ordovician strata in the northern Tarim Basin, China. Sedimentary Geology, 2019, vol. 382, pp. 61-74.

39. Soto J.I., Flinch J.F., Tari, G.C. Permo-Triassic basins and Tectonics in Europe, North Africa and the Atlantic Margin. Tectonics and Hydrocarbon Potential, 2017, vol. 1, pp. 3-41

40. Strohmenger C., Voigt E.B., Zimdars J. Sequence stratigraphy and cyclic development of Basal Zechstein carbonate-evaporite deposits with emphasis on Zechstein 2 off-platform carbonates (Upper Permian, Northeast Germany). Sedimentary Geology, 1996, vol. 102, pp. 33-54.

41. Warren J.K Evaporites through time: tectonic, climatic and eustatic controls in marine and nonmarine deposits. Earth-Science Reviews, 2010, vol. 98, pp. 217-268.

42. Lageweg W.I., Feldman H. Process-based modelling of morphodynamics and bar architecture in confined basins with fluvial and tidal currents. Marine Geology, 2018, vol. 398, pp. 35-47.

43. Virolle M., Féniès H., Brigaud B., Bourillot R., Portier E.J., Patrier P., Beaufort D., Jalón-Rojas I., Derriennic H., Miska S. Fa- 
cies associations, detrital clay grain coats and mineralogical characterization of the Gironde estuary tidal bars. A modern analogue for deeply buried estuarine sandstone reservoirs. Marine and $P e$ troleum Geology, 2020, vol. 114. pp. 104225-104232.
44. Dai-du F., Yuan W., Min L. Classifications, sedimentary features and facies associations of tidal flats. Journal of Palaeogeography, 2013, vol. 2, pp. 66-80.

Received: 9 December 2020.

\section{Information about the authors}

Alexey V. Plyusnin, student, Perm State National Research University.

Alexander I. Sulima, postgraduate student, Perm State National Research University.

Vladislav D. Timofeev, student, Perm State National Research University.

Dmitry V. Koval, student, Perm State National Research University.

Ksenia V. Dementyeva, graduate student, Perm State National Research University. 